\title{
7. SUMMARY AND PRELIMINARY CONCLUSIONS, ODP LEG 104 ${ }^{1}$
}

\author{
Olav Eldholm, Department of Geology, University of Oslo, Oslo, Norway² \\ Jörn Thiede, Geologisch-Paläontologisches Institut und Museum, Christian-Albrechts-Universität, \\ Kiel, Federal Republic of Germany ${ }^{2}$ \\ Elliott Taylor, Ocean Drilling Program, Texas A\&M University, College Station, Texas ${ }^{2}$ \\ and \\ Shipboard Scientific Party ${ }^{3}$
}

\section{INTRODUCTION}

The ODP Leg 104 drilling program was designed to study the nature and origin of the Vøring marginal high and the Cenozoic paleoenvironment of the Norwegian-Greenland Sea. In particular, drilling was planned to provide information about the volcanic, structural, depositional, and climatic history of a relatively young passive continental margin that has been mapped extensively by geophysical surveys.

The outer Vøring Plateau (Figs. 1, 2), bounded landward by the Vøring Plateau Escarpment, forms a buried, marginal structural high with respect to the adjacent Lofoten and Norway deep basins on the seaward side, and the Møre and Vøring sedimentary basins on the landward side. Below a relatively thin cover of Cenozoic sediments, the top of the high is marked by a smooth, strongly reflecting horizon identified as lower Eocene basalt by drilling during DSDP Leg 38 (Talwani, Udintsev, et al., 1976). Beneath the basalt there are locally well-developed wedges of seaward-dipping reflector sequences. The innermost part of the sequence rests on a band of low-frequency reflectors of which the upper, most prominent, often is referred to as reflector K (Talwani et al., 1983; Hinz et al., 1984). Similar features have recently been documented from many of the world's passive margins.

The primary drilling objective was to determine the nature and composition of the dipping sequence and base reflector $\mathrm{K}$

${ }^{1}$ Eldholm, O., Thiede, J., Taylor, E., et al., 1987. Proc., Init. Repts. (Pt. A), $O D P, 104$.

2 Addresses: (Eldholm) Department of Geology, University of Oslo, P.O. Box 1047, Blindern, Oslo 3, N-0316, Norway; (Thiede) Geologisch-Paläontologisches Institut und Museum, Christian-Albrechts-Universität, Olshausenstr. 40, D-2300 Kiel, Federal Republic of Germany; (Taylor) Ocean Drilling Program, Texas A\&M University, College Station, TX 77840.

3 Olav Eldholm, (Co-Chief Scientist), University of Oslo, Oslo, Norway; Jörn Thiede (Co-Chief Scientist), Christian-Albrechts-Universität, Kiel, FRG; Elliott Taylor (Staff Scientist), ODP, Texas A\&M University, College Station, TX; Colleen Barton, Stanford University, Stanford, CA; Kjell Bjorklund, University of Oslo, Oslo, Norway; Ulrich Bleil, Universität Bremen, Bremen, FRG; Paul R. Ciesielski, University of Florida, Gainesville, FL; Alain Desprairies, Université de Paris Sud, Orsay, France; Diane Donnally, Amoco Production Co., New Orleans, LA: Claude Froget, Faculté des Sciences de Luminy, Marseille, France; Robert Goll, IKU/SINTEF, Trondheim, Norway; Rudiger Henrich, Christian-AlbrechtsUniversität, Kiel, FRG; Eystein Jansen, University of Bergen, Bergen, Norway; Larry Krissek, Ohio State University, Columbus, OH; Keith Kvenvolden, USGS, Menlo Park, CA; Anne LeHuray, Lamont-Doherty Geological Observatory, Palisades, NY; David Love, University of Waterloo, Ontario, Canada; Peter Lysne, Sandia National Laboratory, Albuquerque, NM; Thomas McDonald, Texas A\&M University, College Station, TX; Peta Mudie, Geological Survey of Canada, Nova Scotia, Canada; Lisa Osterman, Smithsonian Institution, Washington, DC; Lindsay Parson, Institute of Oceanographic Sciences, Surrey, UK; Joseph Phillips, University of Texas, Austin, TX; Alan Pittenger, Texas A\&M University, College Station, TX; Gunnbjørg Qvale, Norsk Hydro, Oslo, Norway; Günther Schönharting, University of Copenhagen, Copenhagen, Denmark; Lothar Viereck, Ruhr Universität, Bochum, FRG.
(Fig. 2). In addition, drilling was designed to document further the nature and composition of the lower Eocene basalt to give information about the subsidence and depositional history of the marginal high relative to that of the adjacent basins. This information should provide important constraints as to mode and timing of the emplacement of the different rock complexes, the location of the continent-ocean boundary, and early evolutionary history of the passive continental margin.

The Norwegian-Greenland Sea is the northernmost part of the Atlantic Ocean where cold North Atlantic deep water (NADW) is formed. The NADW flows south across the Greenland-Scotland Ridge, through the Atlantic Ocean, and into the adjacent deep Pacific and Indian ocean basins. This process of bottom-water formation developed during the Cenozoic as a consequence of the Northern Hemisphere glaciation and is reflected by the composition and distribution of pelagic sediments in the Norwegian-Greenland Sea. The outflow of cold bottom water is balanced by the inflow of relatively warm surface water from the Atlantic across the eastern part of the Greenland-Scotland Ridge. This surface current, the Norwegian Current, trails the Norwegian continental margin and influences the climate of the entire northwestern part of Europe.

The secondary drilling objective was to provide information about the Cenozoic paleoenvironment of the Norwegian-Greenland Sea; specifically, coring results were meant to relate the paleoceanographic history of the Norwegian-Greenland Sea to the influence of the Norwegian Current, which in turn is a continuation of the Gulf Stream system into the northern polar basins. We hoped to describe the paleoclimatic history of the Northern Hemisphere with particular attention to the initiation, sequence, and variability of the glacial-interglacial fluctuations and to obtain data about the Cenozoic evolution of floras and faunas in response to the paleoclimatic and paleoceanographic processes.

Eight holes were drilled at three sites during Leg 104 (Figs. 1 and 2). A deep penetration site (642) is flanked by sites near the base of the Vøring Plateau (643) and in the Vøring Basin (644). The three drill sites form a short transect roughly perpendicular to the Vøring Plateau continental margin. Site 642, primarily designed to resolve the nature and origin of the Vøring Marginal High, also forms a center point of a paleoenvironmental transect of drill holes. This site transect allows us to study the Norwegian Sea Cenozoic paleoenvironment at different water depths and distances from land, and in distinct geological positions.

At Site 642 (Holes 642A through 642E) we drilled through a 320-m-thick, mainly Neogene, sedimentary section and into $910 \mathrm{~m}$ of volcanic flows and thin, interbedded volcaniclastic sediments (Fig. 3). We believe we drilled through the entire dipping reflector sequence and into about $130 \mathrm{~m}$ of the underlying rocks. Site 643 , which reached oceanic basement after drilling $565 \mathrm{~m}$ of sediments, also contains a thick Paleogene sequence (Fig. 3). Finally, Site 644 (Holes 644A and 644B) operations 


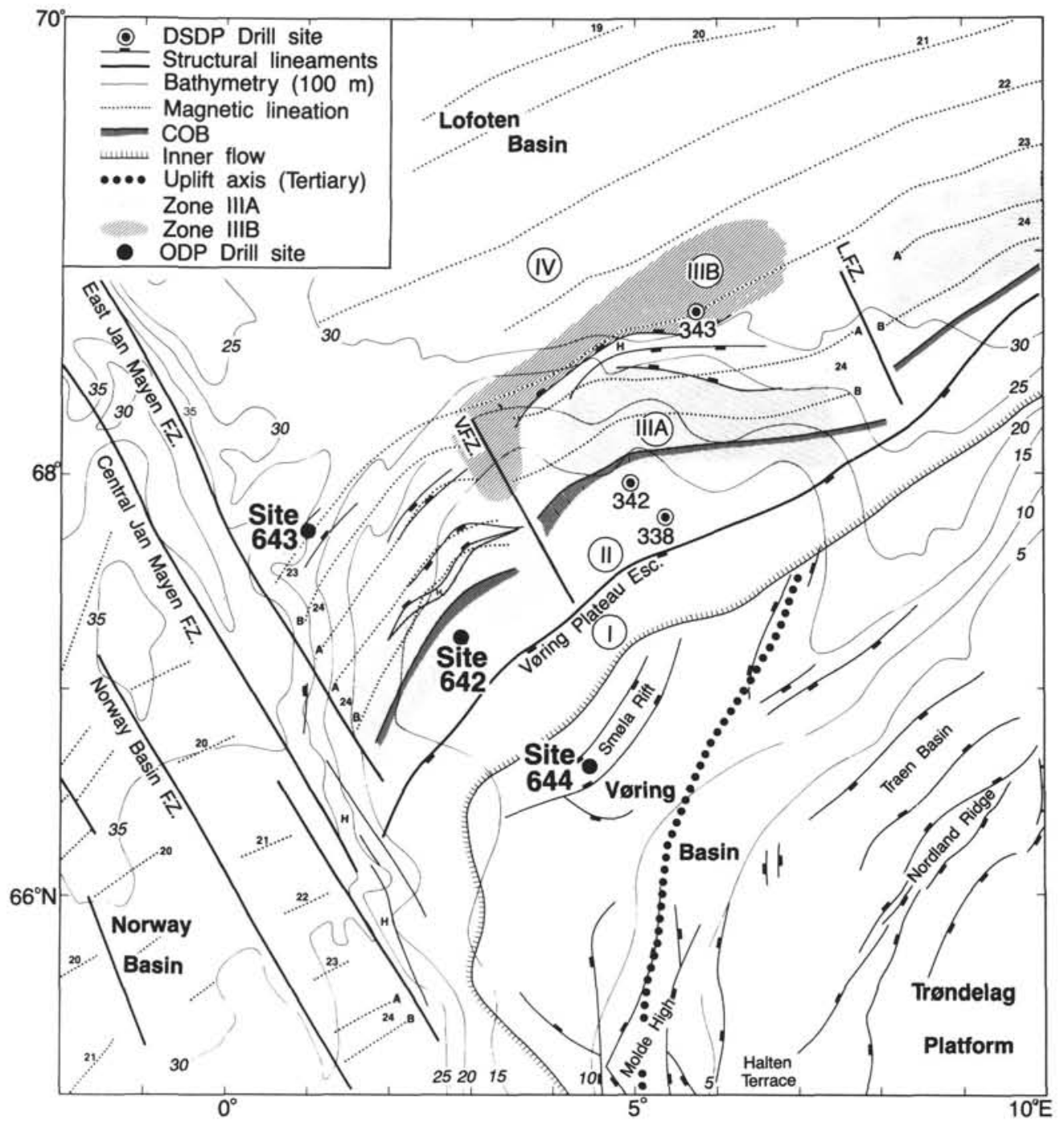

Figure 1. Main structural features, seafloor-spreading magnetic anomalies and simplified bathymetry (hundreds of meters) in the Norwegian-Greenland Sea. Zone III outlines the extent of the seaward-dipping reflectors. From Skogseid and Eldholm (unpublished).

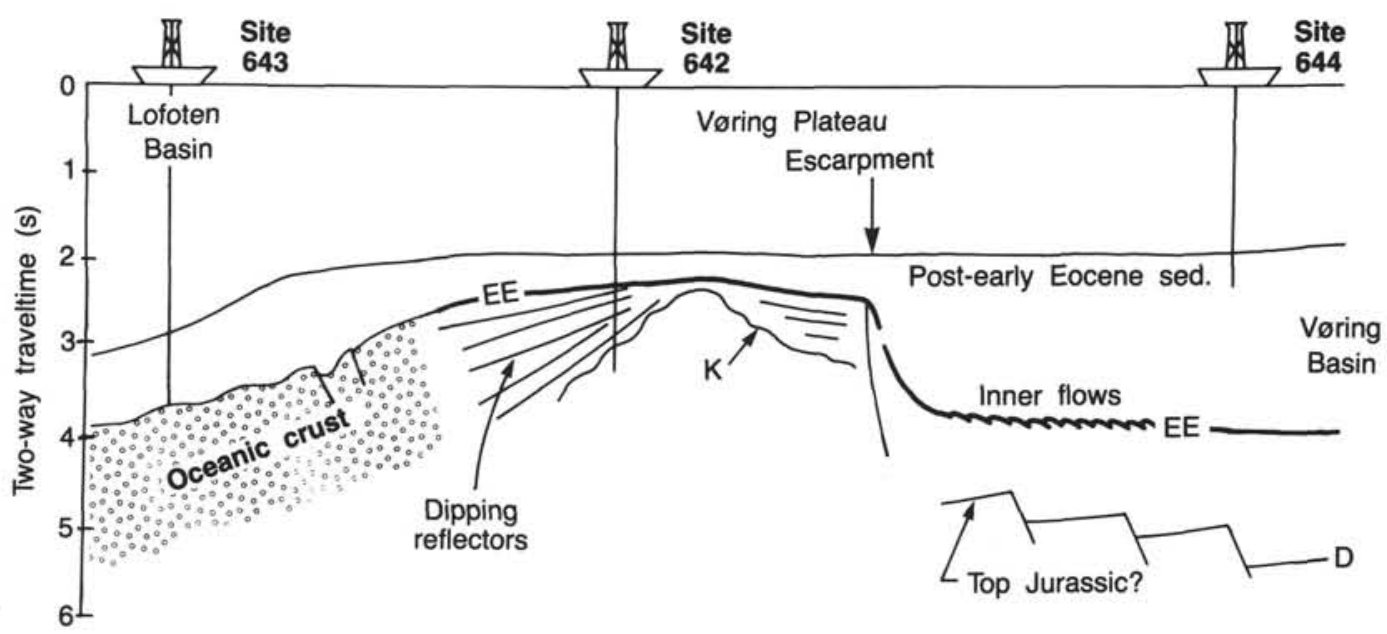

Figure 2. Simplified schematic section across the Vøring Plateau, indicating the general setting of the drill sites. Modified from Eldholm et al. (1984). 

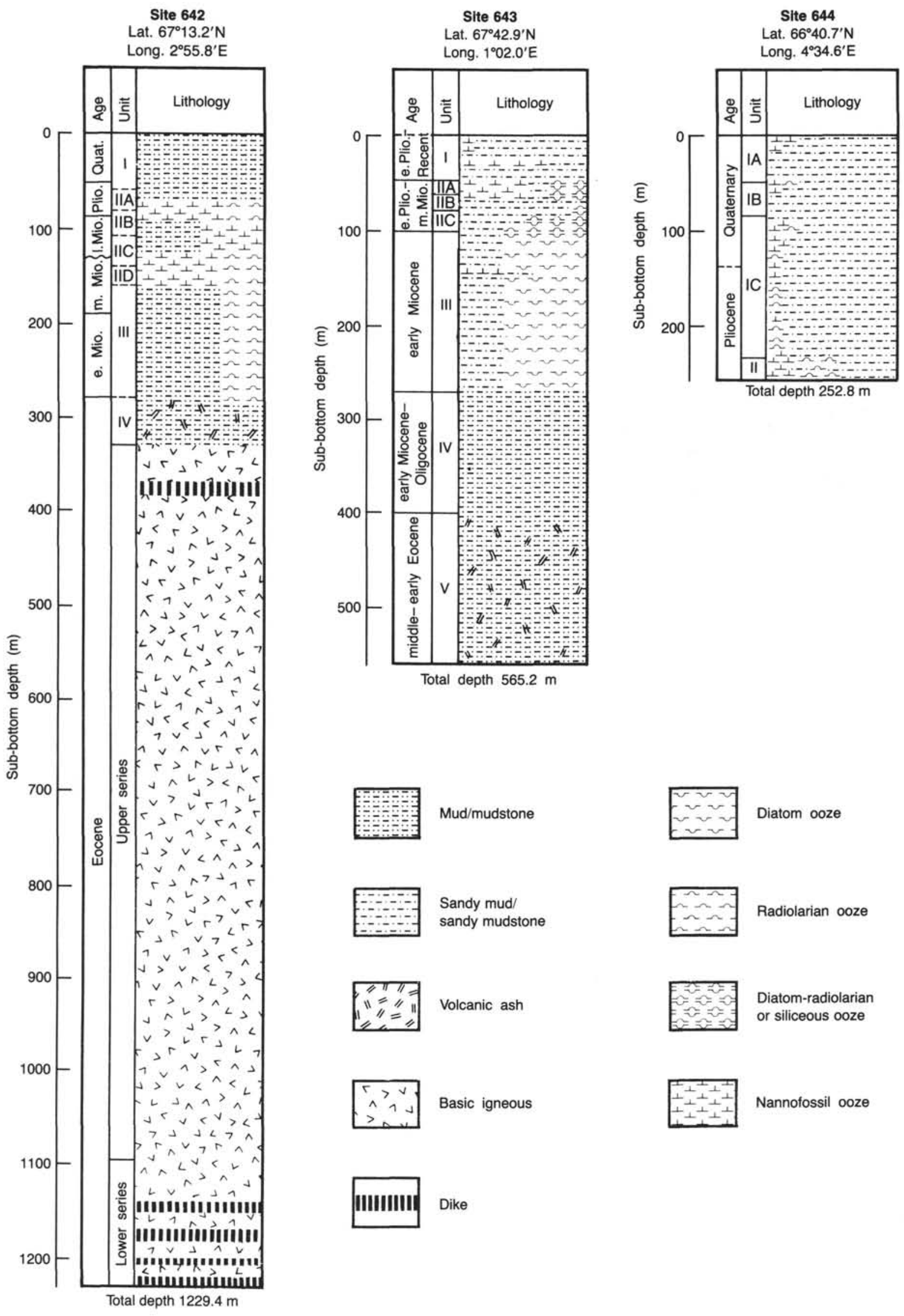

Figure 3. Generalized stratigraphic sections for ODP Leg 104 sites. 
cored through a $250-\mathrm{m}$ sequence of stratigraphically highly resolved Quaternary and upper Pliocene sediments (Fig. 3). The drilled sedimentary sections from all sites are particularly valuable throughout the Neogene and Quaternary and collectively may be considered as a key stratigraphic reference section for northern high latitudes. The main drilling results are compiled in summary diagrams (Figs. 4-8).

In this chapter we summarize the ODP drilling results obtained at the Vøring Plateau in the summer of 1985. Although we were successful in accomplishing all our major drilling objectives, we do stress the preliminary nature of these results and inferences, which are based almost exclusively upon the analyses performed by the shipboard scientific party during the leg and on any new data made available at the postcruise meeting in College Station, Texas, 24-28 April 1986.

\section{PRINCIPAL DRILLING RESULTS}

Location and key drilling data for each hole are listed in Table 1 .

\section{Site 642}

Site 642 , consisting of five holes within $450 \mathrm{~m}$ of each other, is located at the outer Vøring Plateau in water depths of 1289 to $1293 \mathrm{~m}$, and over the innermost wedge of a dipping reflector sequence (Fig. 1). The total drilled depth below the seafloor was $1229.4 \mathrm{~m} ; 320 \mathrm{~m}$ consisted predominantly of pelagic-hemipelagic Neogene and Quaternary sediment overlying a 910-mthick volcanic, mostly basaltic, sequence with interbedded pyroclastic sediments. The shipboard studies results are summarized in Figures 4 through 6 . The Eocene-Miocene hiatus is illustrated in Figure 9; the transition from the lower to the upper volcanic series is shown in Figure 10. The sedimentary section comprises four main lithologic units:

\section{Unit I. 0-65 m}

Late Pliocene to Recent. Interbedded dark, carbonate-poor glacial muds and light, carbonate-rich, interglacial marine sandy muds.

\section{Unit II. 65-157 m}

Middle Miocene to late Pliocene. The unit is divided into four subunits: Subunit IIA. 70-83 m. Early Pliocene to late Pliocene. Nannofossil oozes with minor diatom-nannofossil oozes and muds. Subunit IIB. 83-108 m. Late Miocene. Siliceous muds and siliceous oozes. Subunit IIC. 108-146 m. Middle to late Miocene. Interbedded nannofossil oozes, marly nannofossil oozes, siliceous nannofossil oozes, siliceous muds, siliceous oozes. Subunit IID. 146-157 m. Middle Miocene. Mixed siliceous-calcareous oozes with minor siliceous muds and nannofossil oozes.

\section{Unit III. 157-278 m}

Early Miocene to middle Miocene. Siliceous muds and siliceous oozes.

\section{Unit IV. 278-327 m}

Eocene. Volcaniclastic and altered volcaniclastic muds, sandy muds, and sands.

In addition, about 50 discrete ash layers within the units mentioned document late Cenozoic volcanicism.

The entire volcanic section below the sedimentary units contains 146 volcanic flows, 60 volcaniclastic sediment layers, and 7 possible dikes. The volcanic section is divided into upper and lower series that are distinctive in textural, structural, physi$\mathrm{cal}$, mineralogical, and chemical characteristics of the flows, as well as in the compositions of interlayered volcaniclastic sediments. Both series have been deposited in a terrestrial, subaerial environment.

\section{Upper Series. $327-1087 m$}

Late-middle(?) to late-early Eocene. The upper series consists of 120 flows. The flows are aphyric to moderately plagioclase and olivine-phyric, with $\mathrm{N}$-type MORB composition. These tholeiitic lava flows have strong affinities with other plateau basalts within the Paleogene North Atlantic Volcanic Province and mid-Atlantic Ridge basalts from the Reykjanes Ridge. Two varieties of flows, differing in granularity, crystallinity, internal flow fabric, physical properties, and average thickness, make up the upper series. However, these flows are indistinguishable chemically. Fifty-three interlayered volcaniclastic sediment units, which make up about $4 \%$ of the series, are mostly basaltic vitric tuffs.

\section{Lower Series. 1087-1229 m}

Early Eocene(?). The lower series is characterized by glassy, variolitic, and microcrystalline flows. There are two magma types, one derived by partial fusion of sedimentary or metasedimentary rocks, the other from contamination of the upper series tholeiites by the crustal melt. Interbedded volcaniclastic sedimentary rocks make up about $29 \%$ of the lower series, which contains significant quantities of quartz and mica of continental origin. A few fragments of leucocratic gneiss and quartzmica schist occur in the lowest sediment drilled and within an ignimbrite unit. Two of the four dikes are chemically comparable with their bounding flows, whereas the other two are of tholeiitic composition.

\section{Temporal Framework}

A preliminary temporal framework for Site 642 has been established from biostratigraphic and paleomagnetic results. It includes the Paleogene volcanic eruptions emplacing the 146 basaltic flows and the depositional environments of the interbedded sediments, as well as the overlying pelagic to hemipelagic Neogene and Quaternary sediments. Although the present stratigraphic interpretation is of variable precision, the correlation of the biostratigraphic and magnetostratigraphic data with an absolute time scale provides a reasonably well-documented timing for the Cenozoic history of the Outer Vøring Plateau. However, shore-based studies are expected to improve the stratigraphy considerably, as these include detailed biostratigraphic work and radiometric dating of the volcanic rocks.

Volcaniclastic deposits occur between the individual flows within the volcanic series, in Unit IV overlying the volcanics, and as discrete ash layers dispersed in the Neogene and Quaternary sequences. The dating of the volcaniclastic sediments below the lower Miocene unconformity (Fig. 9), based solely on palynomorphs and to a minor extent silicoflagellates, shows a downhole progression from the late to early Eocene. However, the long ranges of most species within these volcaniclastic units could also satisfy other models. The biostratigraphic data yield ages from early Eocene (52-58 Ma) as a maximum for the lower volcanic series, to late Eocene for Unit IV on top of the upper volcanic series (Fig. 48, Site 642 chapter).

Based on the reversed magnetic polarity of the entire volcanic series, the late/middle Eocene potassium-argon ages of basalts at DSDP Sites 338 and 342 (Kharin et al., 1976) and the existence of lower Eocene sediments above the basalt at DSDP Site 338 , we suggest an early Eocene age for the upper series. The lower series is inferred to be slightly older than the upper series. Inconclusive data have not allowed us to evaluate whether the two volcanic series represent relatively short-lived volcanic events restricted to certain age intervals, or if these are the result of continuous longer lasting volcanic activity. It appears, however, that a rapid succession of flows of variable length, and possibly derived from several sources, led to the formation of the dipping reflector sequence. Although both volcanic series 
Table 1. Leg 104 drilling information summary.

\begin{tabular}{|c|c|c|c|c|c|c|c|c|c|c|}
\hline Hole & $\begin{array}{l}\text { Latitude } \\
(\mathrm{N})\end{array}$ & $\begin{array}{l}\text { Longitude } \\
\text { (E) }\end{array}$ & $\begin{array}{l}\text { Water } \\
\text { depth } \\
\text { (m) }\end{array}$ & $\begin{array}{l}\text { Number } \\
\text { of cores }\end{array}$ & $\begin{array}{c}\text { Meters } \\
\text { cored }\end{array}$ & $\begin{array}{l}\text { Meters } \\
\text { recovered }\end{array}$ & $\begin{array}{l}\text { Percent } \\
\text { recovered }\end{array}$ & $\begin{array}{l}\text { Meters } \\
\text { drilled }\end{array}$ & $\begin{array}{l}\text { Total } \\
\text { penet. } \\
(\mathrm{m})\end{array}$ & $\begin{array}{c}\text { Time on } \\
\text { hole } \\
\text { (hr) }\end{array}$ \\
\hline $642 \mathrm{~A}$ & $67^{\circ} 13.5^{\prime} \mathrm{N}$ & $2^{\circ} 55.7^{\prime} \mathrm{E}$ & 1292.7 & 1 & 9.5 & 9.9 & 104 & 1.3 & 10.8 & 11.00 \\
\hline $642 B$ & $67^{\circ} 13.5^{\prime} \mathrm{N}$ & $2^{\circ} 55.7^{\prime} \mathrm{E}$ & 1292.7 & 25 & 221.1 & 215.6 & 98 & 0 & 221.1 & 30.00 \\
\hline $642 C$ & $67^{\circ} 13.2^{\prime} \mathrm{N}$ & $2^{\circ} 55.8^{\prime} \mathrm{E}$ & 1292.1 & 24 & 199.6 & 192.8 & 97 & 0 & 199.6 & 43.75 \\
\hline $642 \mathrm{D}$ & $67^{\circ} 13.2^{\prime} \mathrm{N}$ & $2^{\circ} 55.8^{\prime} \mathrm{E}$ & 1292.1 & 20 & 139.0 & 117.0 & 84 & 189.9 & 328.9 & 56.25 \\
\hline $642 \mathrm{E}$ & $67^{\circ} 13.2^{\prime} \mathrm{N}$ & $2^{\circ} 55.8^{\prime} \mathrm{E}$ & 1289.0 & 107 & 906.9 & 372.6 & 41 & 322.5 & 1229.4 & 695.75 \\
\hline \multicolumn{2}{|c|}{ Totals for Site 642} & & & 177 & 1476.1 & 907.9 & 62 & 513.7 & 1989.8 & 836.75 \\
\hline $643 \mathrm{~A}$ & $67^{\circ} 42.9^{\prime} \mathrm{N}$ & $1^{\circ} 02.0^{\prime} \mathrm{E}$ & 2779.8 & 61 & 565.2 & 449.2 & 79 & - & 565.2 & 139.75 \\
\hline $644 \mathrm{~A}$ & $66^{\circ} 40.7^{\prime} \mathrm{N}$ & $4^{\circ} 34.6^{\prime} \mathrm{E}$ & 1226.3 & 34 & 252.8 & 238.4 & 94 & - & 252.8 & 34.75 \\
\hline $644 B$ & $66^{\circ} 40.7^{\prime} \mathrm{N}$ & $4^{\circ} 34.6^{\prime} \mathrm{E}$ & 1225.9 & 15 & 127.7 & 103.6 & 81 & - & 127.7 & 20.25 \\
\hline \multicolumn{2}{|c|}{ Totals for Site 644} & & & 49 & 380.5 & 342.0 & 89 & - & 380.5 & 55.00 \\
\hline \multicolumn{2}{|c|}{ Grand totals } & & & 287 & 2421.8 & 1699.1 & 70 & 513.7 & 2935.5 & 1031.50 \\
\hline
\end{tabular}

were laid down subaerially, there are indications of shortlived marine transgressions. We recognize the presence of pelagic marine microfossils (siliceous and organic walled) in the upper series, but presently we cannot exclude the possibility that some of this material is reworked.

The pelagic to hemipelagic deposits overlying the volcanic sequence have been dated rather precisely by a combination of datum planes from biostratigraphic data of palynomorphs, diatoms, silicoflagellates, calcareous nannofossils, calcispheres, radiolarians, benthic and planktonic foraminifers and magnetostratigraphic data (Figs. 4-5). However, the magnetostratigraphic data have presently proven useful only for the Pliocene and Quaternary sequences. Except for some disputed possible short hiatuses in the Neogene part of the section, which may simply represent zones of very low sediment accumulation rates, there is good agreement among the various biostratigraphic data. In general, we document continuous sedimentation for long Neogene intervals, although sedimentation rates seem to have fluctuated at irregular intervals.

Approximately 50 ash layers have been detected in the Neogene and Quaternary sediments. The identified tephra horizons occur in various lithological forms, but the most prominent ones comprise discrete layers of tephra composed of unconsolidated, well-sorted, very fine sands and, less commonly, coarse silts. The layers are exclusively 1 - to 10 -cm-thick vitric ashes and are classified according to vesicularity, decreasing coloration, and decreasing refractive index. We suggest these are of air-fall origin. The tephra layers occur with an average frequency of about three layers per $1 \mathrm{~m} . y$., but less often during the past $5 \mathrm{~m}$.y. On the basis of the petrographic data, all tephra layers are of moderately to highly differentiated chemical composition, probably belonging to a common magmatic differentiation sequence (tholeiitic andesite-icelandite-rhyolite). Iceland is the likely eruptive source of most of these tephra layers. Based on the stratigraphic distribution of ash at Site 642, a decrease in the rate of explosive eruptions from the Miocene to the Pliocene-Pleistocene can be assumed. This result contrasts with estimates by Donn and Ninkovich (1980), who proposed an increase in explosive eruptions in the same time span.

\section{Site 643}

Site 643 is located on the lower slope near the foot of the outer Vøring Plateau, seaward of the dipping reflector sequence and in an area underlain by typical oceanic basement dated as magnetic anomaly 23 (Fig. 1). The site also forms the western, and deepest, end of the Leg 104 paleoenvironmental site transect.

The single-bit Hole $643 \mathrm{~A}$, in water $2780 \mathrm{~m}$ deep, penetrated a $565.2-\mathrm{m}$-thick pelagic and hemipelagic sedimentary sequence and terminated in basaltic rubble (Fig. 3). Poor hole conditions prevented further drilling as well as the planned logging program. The shipboard studies results are summarized in Figure 7.

The Cenozoic sedimentary section at Site 643 comprises five lithologic units that in general can be correlated with the lithostratigraphic record of Site 642:

\section{Unit I. 0-49.4 m}

Early Pleistocene to Recent. Glacial-interglacial sedimentary cycles consisting of alternating dark, relatively carbonate-poor, and light, carbonate-rich layers of muds, sandy muds, and sandy calcareous muds. Evidence of moderate slumping was found.

\section{Unit II. 49.4-100.2 m}

Late Miocene to late Pliocene. This unit was affected by slumping. Based on compositional data, it is subdivided into three subunits. Subunit IIA. 49.4-63.8 m. Late Pliocene. Siliceous nannofossil ooze. Subunit IIB. 63.8-81.3 m. Late Miocene-early Pliocene. Predominantly terrigenous, containing siliceous muds and mud with only minor amounts of nannofossil ooze. Subunit IIC. 81.3-100.2 m. Late Miocene. Predominantly diatomaceous nannofossil ooze.

\section{Unit III. 100.2-274.1 m}

Early-late Miocene. Primarily diatom oozes.

\section{Unit IV. 274.1-400.7 m}

Early Miocene. Monotonous dark, extremely fossil-poor terrigenous mudstones and minor gray nannofossil chalk.

\section{Unit V. 400.7-565.1 m}

Early(?)-middle Eocene to late Oligocene. Predominantly dark greenish gray to dark reddish brown and grayish brown zeolitic mudstones, most of which are intensively compacted and laminated. The lowermost two cores contain pebble- to cobblesized basaltic fragments, a polymict conglomerate of pyroclastic rocks and a dark basaltic conglomerate. This may indicate that drilling terminated in a basal sequence overlying oceanic basement.

\section{Temporal Framework}

The temporal framework for this site, based on micropaleontological and paleomagnetic data, cannot match the detail and precision established for the Neogene sequence at Site 642. Nevertheless, it provides enough information to establish a preliminary sequence of events controlling the depositional environment. Because of its deep water location, low sedimentation rates, and intensive diagenesis in the deeper part of the cored section, many of the fossil groups at Site 643 were not as well preserved as those in Site 642 . The most extensive microfossil groups are the palynomorphs and siliceous plankton, whereas 


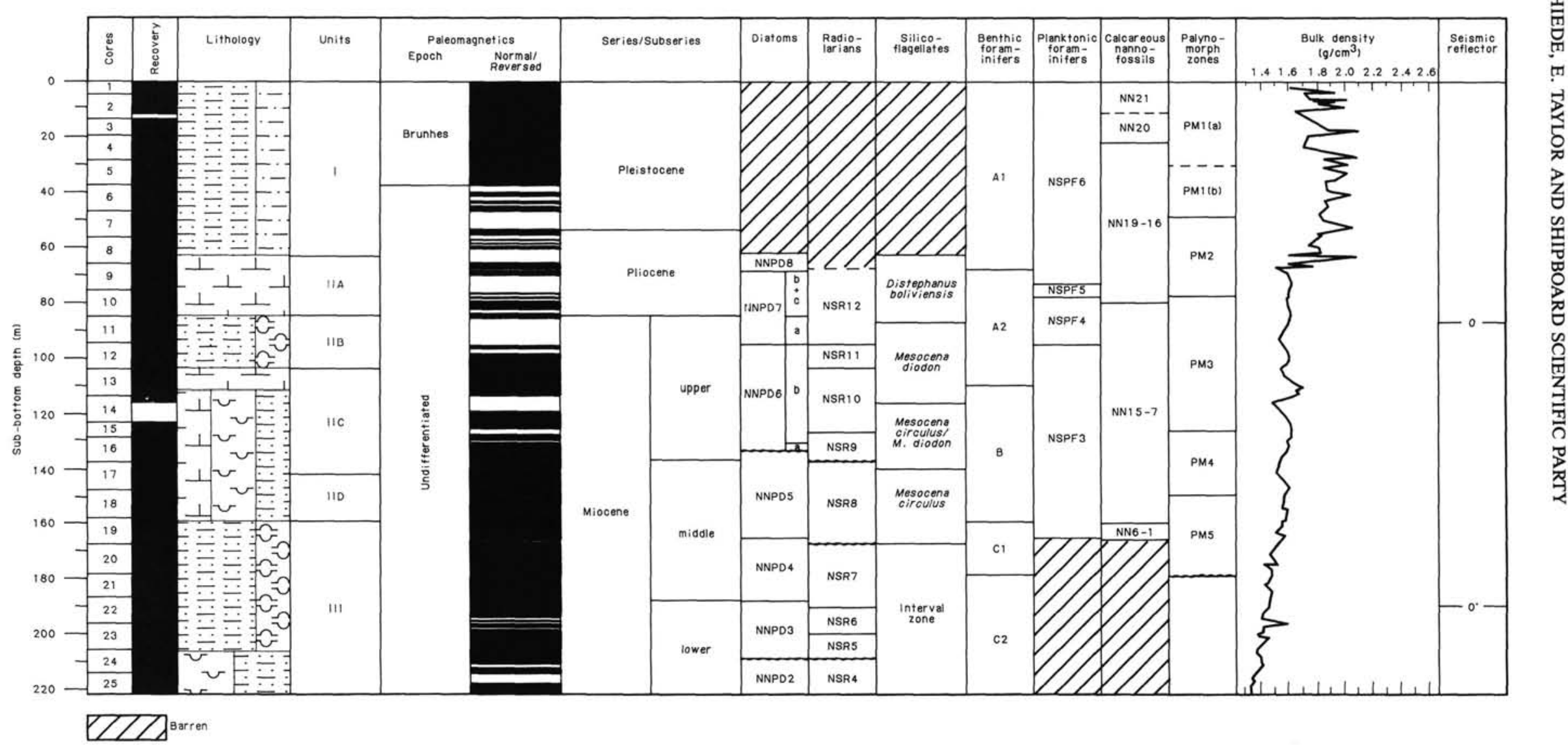

Figure 4. Summary diagrams for Holes 642A and 642B. 


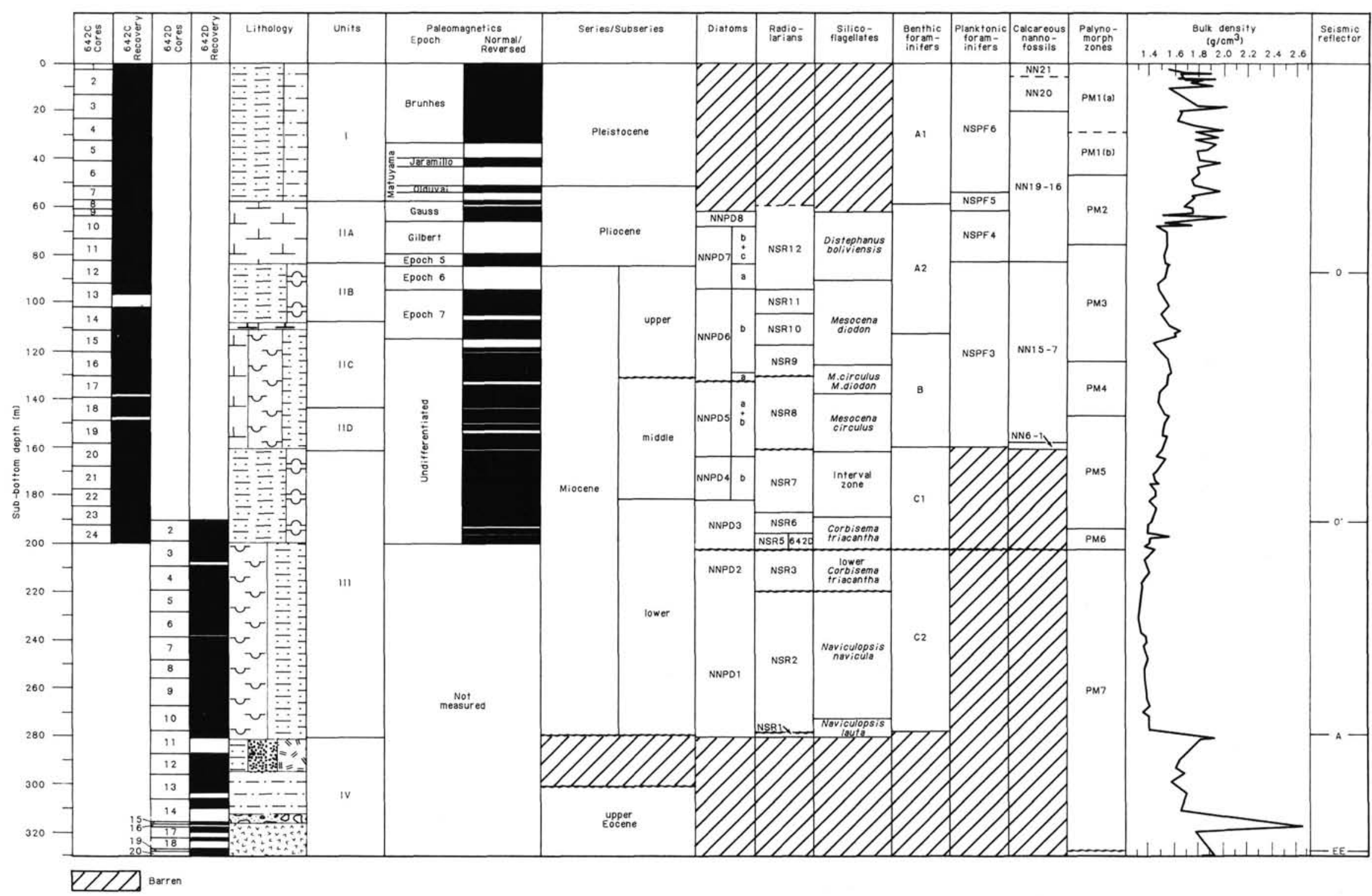

Figure 5. Summary diagrams for Holes $642 \mathrm{C}$ and 642D. 


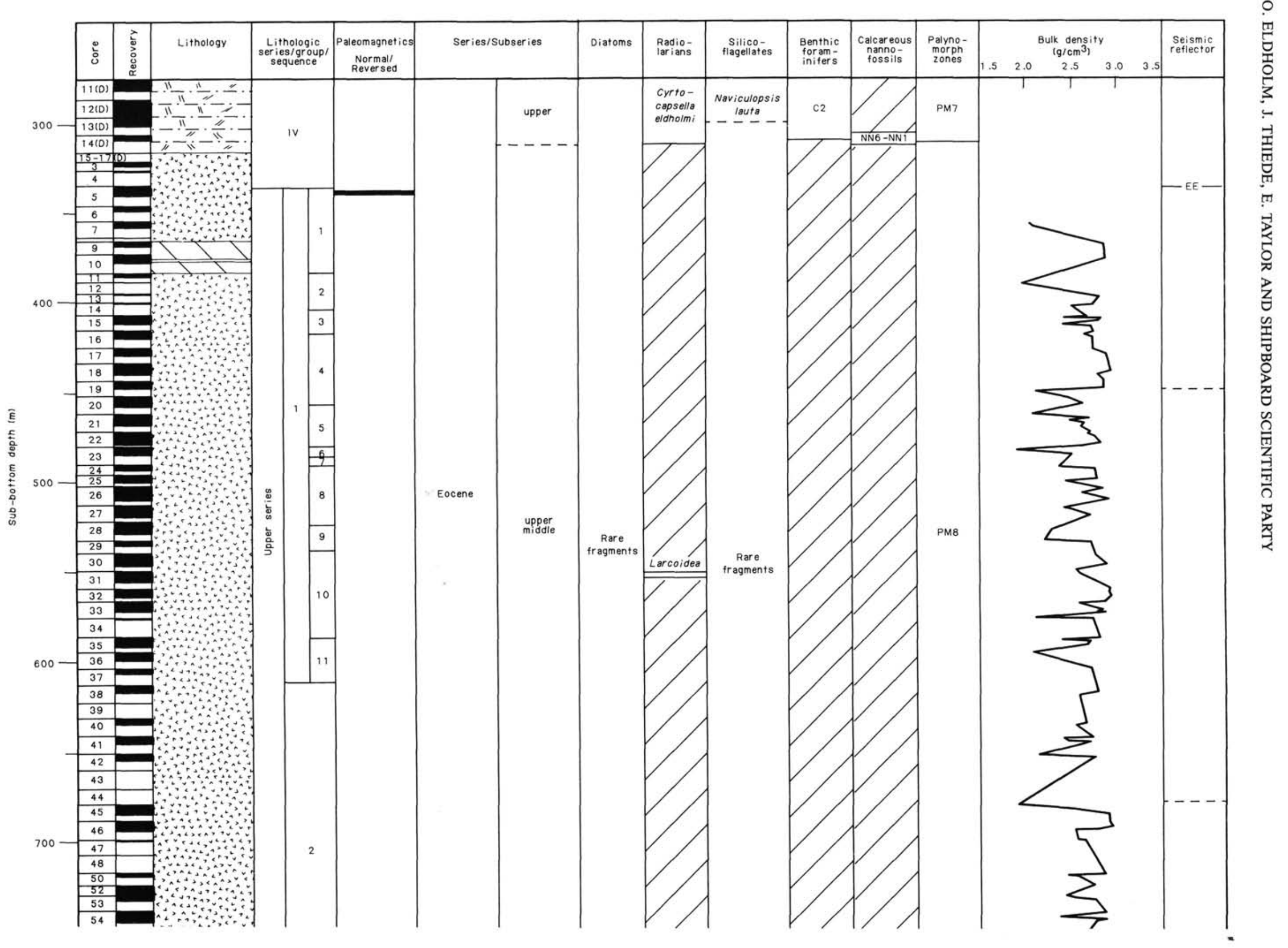




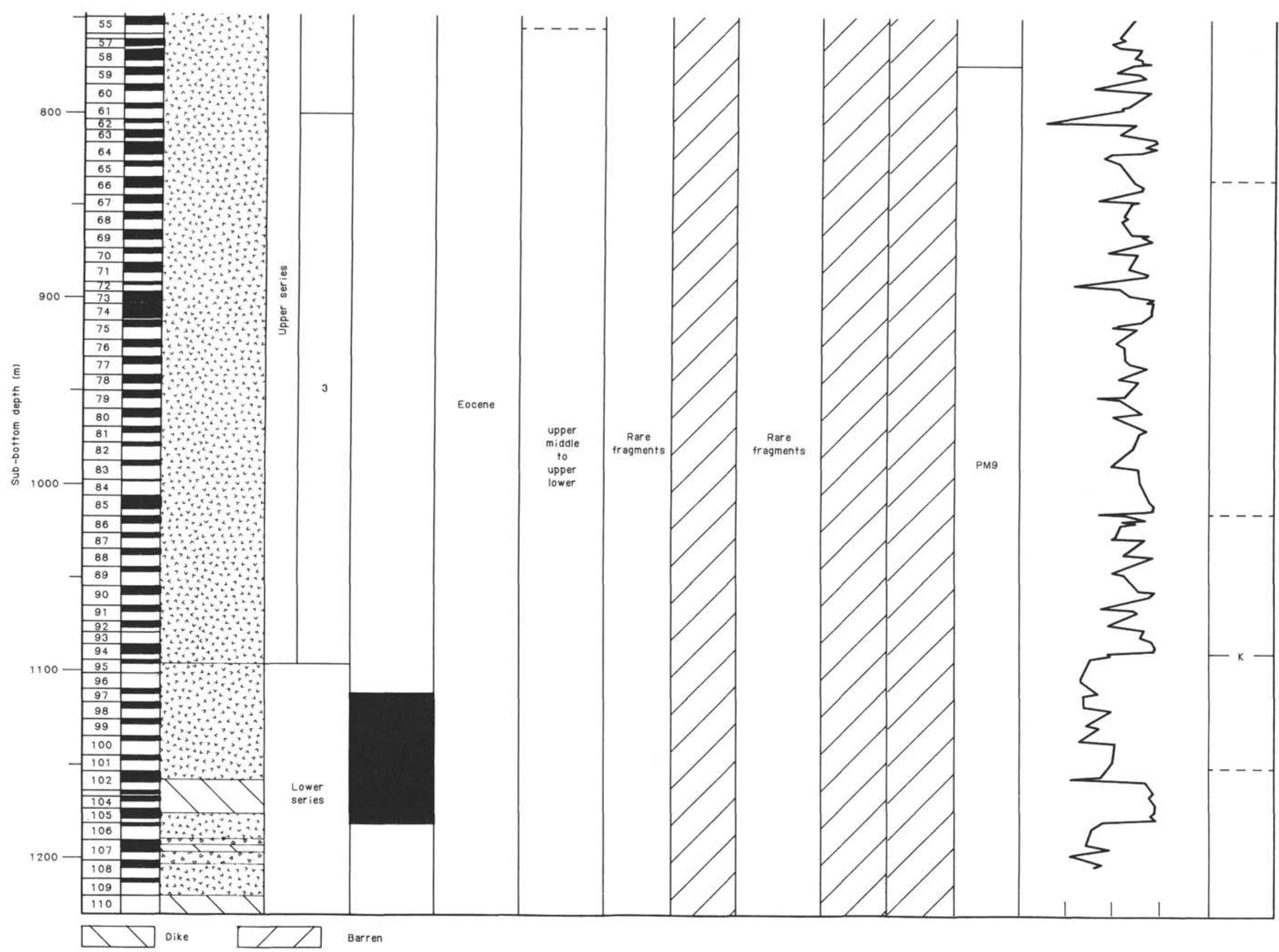




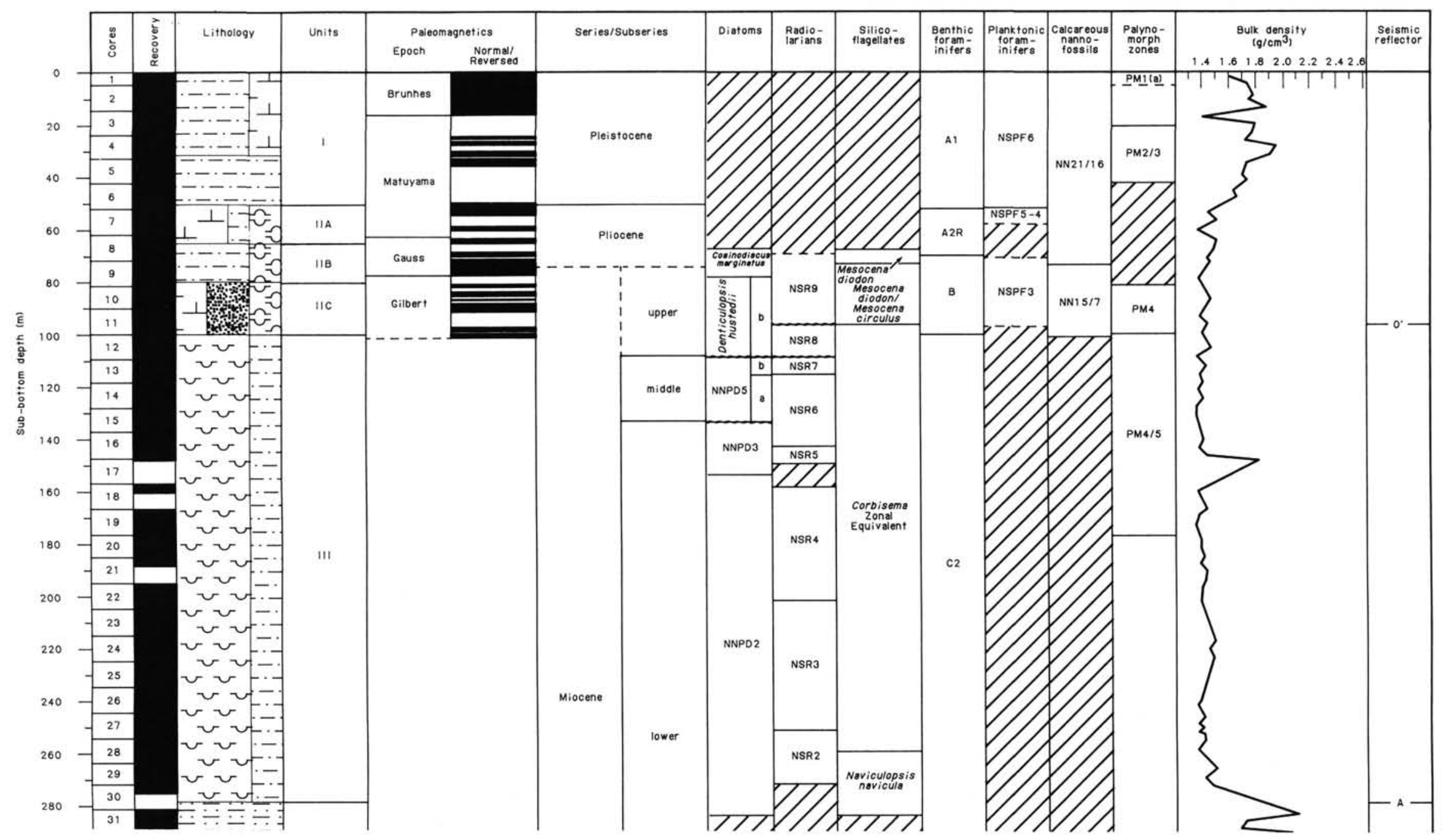




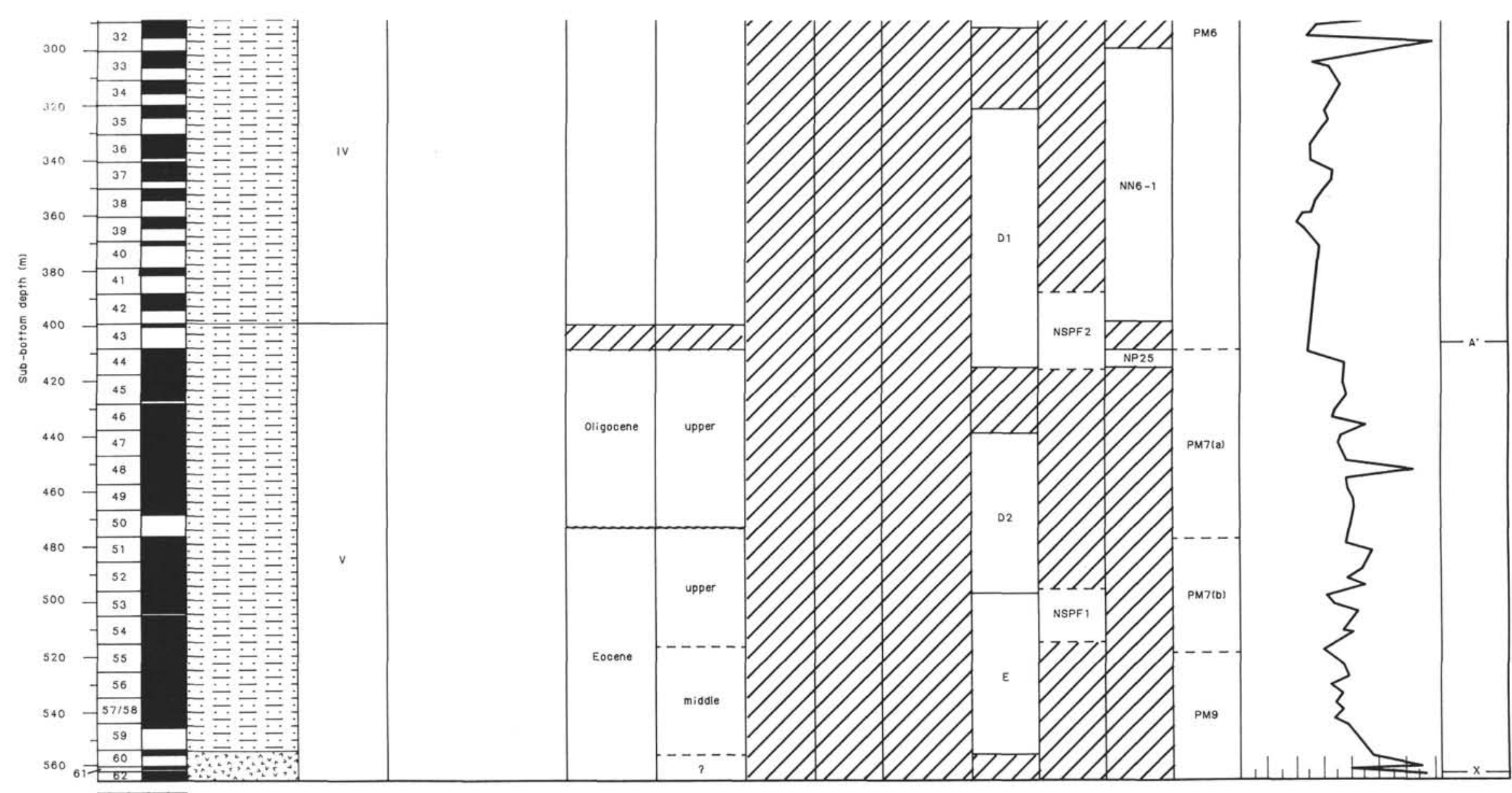

VI7Z/ Barren

Figure 7. Summary diagram for Hole 643A. 


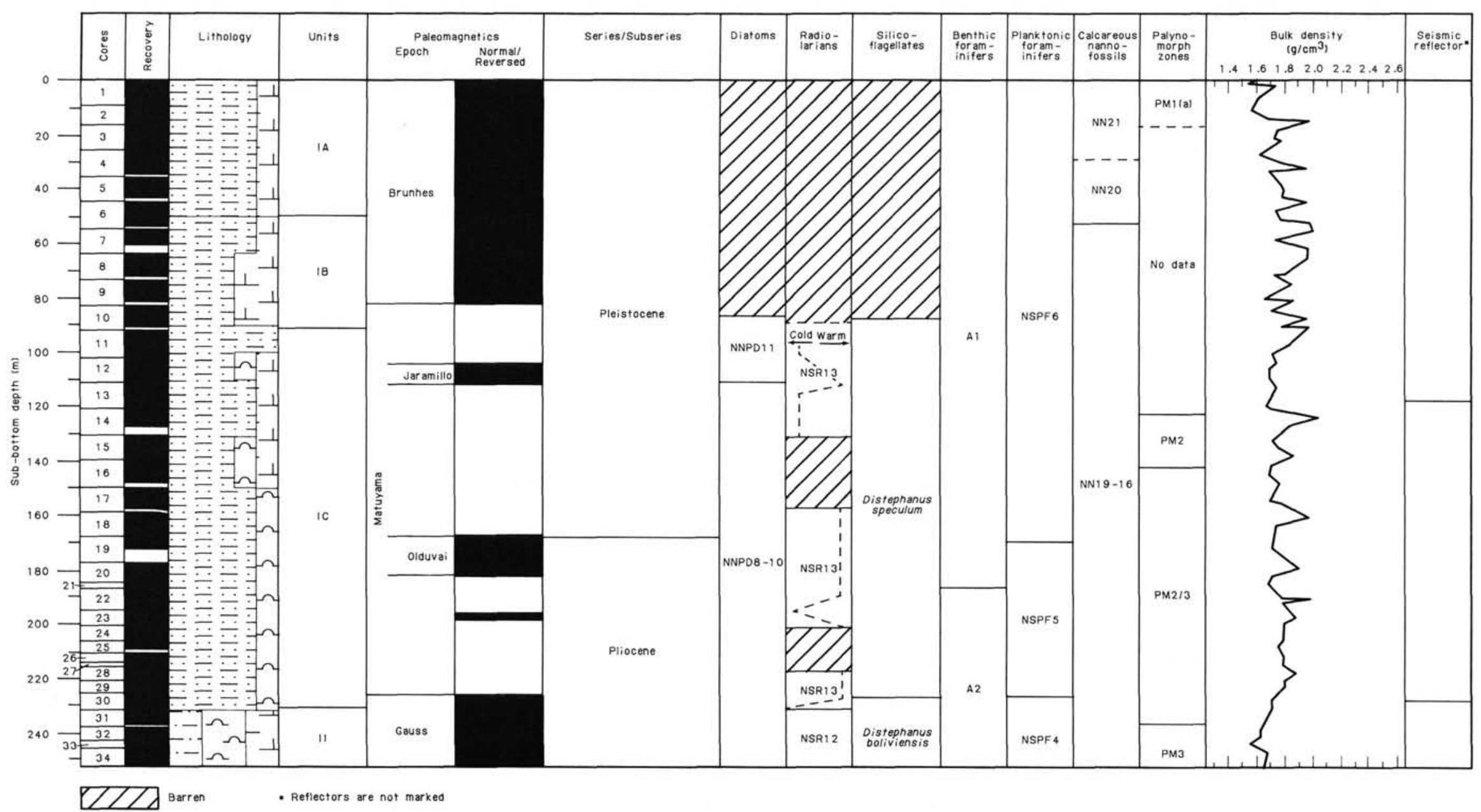

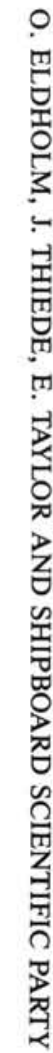

Figure 8. Summary diagram for Hole 644A. 


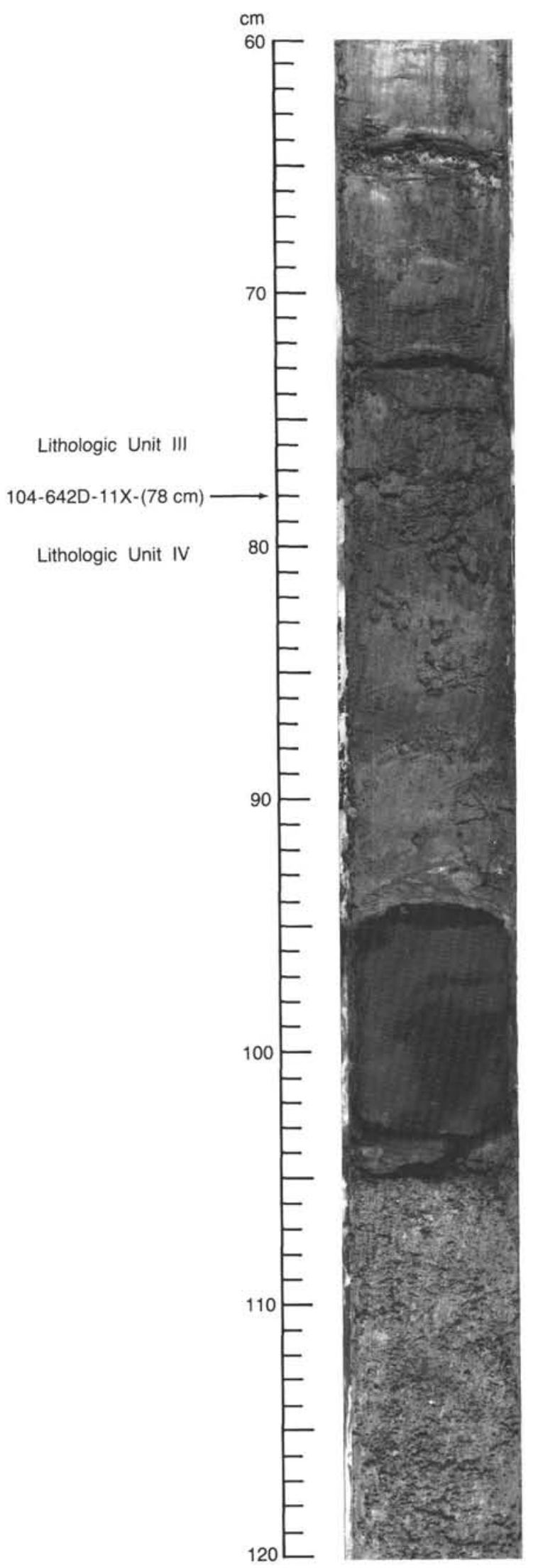

Figure 9. Core photograph of the prominent unconformity in Hole 642D corresponding to the change between lithologic Units III and IV, and seismic horizon A.

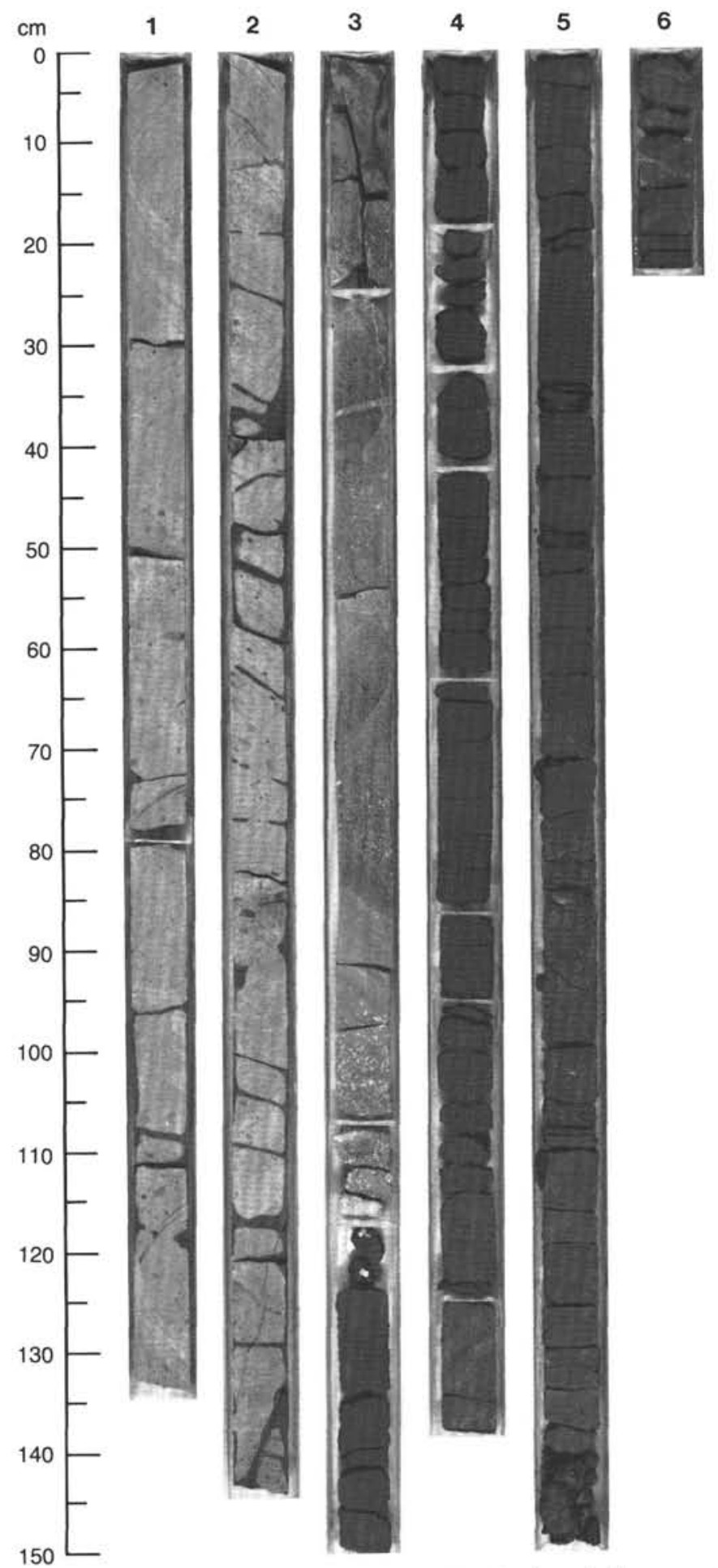

Figure 10. Photograph of Core 104-642E-94R showing the lowermost flow in the upper series and the prominent sediment layer separating the two volcanic series.

calcareous nannofossils and planktonic foraminifers are restricted mainly to the upper part (middle Miocene and younger) and selected intervals in the Paleogene (Fig. 14, Site 643 chapter).

There is no major disagreement about the middle to early Eocene ages of the oldest cores at this site, and the age of the basaltic conglomerates in the bottom of the hole is most likely late-early Eocene. A typical basement unit was not reached, but 
the hole bottomed in volcaniclastic rocks with a conglomeratic unit at the base. A similar conglomerate was drilled at DSDP Site 343. This latter site occupies an equivalent structural position near the base of the plateau further north. A correlation of lithologies at this site with those at Site 643 suggests that the basaltic conglomerate at Site 643 represents the transition to the oceanic basement below. The recovered basalt fragments also have a composition similar to that of oceanic crust. These observations, together with analysis of the seismic reflection profile at this site, indicate that the hole probably terminated in a basal sediment sequence directly overlying the oceanic basement. Thus, the cored section might provide important constraints in terms of the subsidence history.

Eocene faunas and floras are traced through the entire interval between 475 and 565.2 mbsf. The Eocene deposits, however, are overlain by a thinner ( $400-470$ mbsf) Oligocene sediment sequence identified by calcareous nannofossil and planktonic foraminiferal datum planes and palynomorph data. The depth interval $72-400$ mbsf is Miocene in age, based on the good agreement among most of the microfossil groups (Fig. 7). Many discrepancies exist among dates in the Pliocene to Quaternary (0-72 mbsf) interval. Difficulties arose from attempts to correlate the paleomagnetic and biostratigraphic data, and from the presence of slumped intervals in part of the sequence where the biostratigraphic control is poor. The Neogene and Quaternary sequence contains numerous volcanic ashes that can be correlated with great precision to the air-fall tephra layers at Site 642.

Site 643 never experienced shallow-water depositional environments and can be considered the deep-water analog to the DSDP sites on the Vøring Plateau and ODP Site 642. However, the sedimentation rates are higher than anticipated, mainly because of the presence of slumped sediment layers. Nevertheless, the sedimentary section here provides a record of the depositional environments under the seaward boundary of the Norwegian Current in water depths close to the Norwegian Sea basin floors.

\section{Site 644}

Site 644 represents the landward end of the paleoenvironmental transect. The site is located in water $1226 \mathrm{~m}$ in depth, in the Vøring Basin and close to the base of the inner continental slope (Fig. 2, Chapter 1). This basin is an area of high Neogene sedimentation rates and, because of safety reasons, drilling was permitted only to a depth of $250 \mathrm{~m}$. Thus, we expected to core only a relatively young sedimentary sequence. The shipboard science results are summarized in Figure 8.

The upper Neogene and Quaternary sedimentary section has been subdivided into two lithologic units:

\section{Unit I. 0-230.9 m}

Late Pliocene to Recent. Subunit IA. 0-49.9 m. Late Quaternary. Interbedded dark, carbonate-poor, glacial sandy muds and light, interglacial, calcareous muds. Subunit IB. 49.9-84.2 m. Mid- to late Quaternary. Interbedded dark, carbonate-poor and light, interglacial, calcareous muds, sandy calcareous muds, and marly foraminiferal-nannofossil oozes. Subunit IC. 84.2-230.9 $\mathrm{m}$. Late Pliocene to mid-Quaternary. Interbedded dark, carbonate-poor (glacial) muds and sandy muds, and light (interglacial) siliceous muds, siliceous nannofossil muds, and nannofossil muds.

\section{Unit II. 230.9-252.8 m}

Mid-Pliocene. Interbedded siliceous oozes and mixed siliceous nannofossil oozes. Significant quantities of methane were found from about 40 mbsf to the total cored depth. Large gas-expansion cracks were noted in the interval 73-159 mbsf. The gas within these cracks was composed of $45 \%-89 \%$ methane. Ethane, propane, and butane were present at low parts per million (ppm) levels, particularly toward the bottom of the hole. The composition of the gas mixtures indicates that the methane is of biological origin. The other hydrocarbon gases are probably products of very low temperature genesis. These geochemical results contrast with findings at the two previous sites, where the maximum amount of methane was only $23 \mathrm{ppm}$.

\section{Temporal Framework}

Measurements of the remanent magnetic properties have provided a detailed magnetostratigraphic record, which can be correlated with the biostratigraphic data; both data sets are in good agreement and provide a precise, high-resolution temporal framework for paleoenvironmental reconstructions. The base of the hole was assigned an age of about $2.9 \mathrm{Ma}$ (Gauss epoch).

Almost all important oceanic microfossil groups have contributed to the biostratigraphic framework. Siliceous microfossils were not found in the upper $85 \mathrm{~m}$ of the cored section, and only occur rarely below this depth. Diatoms and silicoflagellates are abundant, however, in the lowermost $25 \mathrm{~m}$ of Hole $644 \mathrm{~A}$. Silicoflagellates give an early late Pliocene (Gauss epoch) age to this interval, which is in agreement with the earliest occurrence of Globorotalia inflata. Two stratigraphic boundaries can be defined for planktonic foraminifers, namely N22/N23 and N21; the top of Zone N21 marks the Pliocene-Pleistocene boundary with the last occurrence of left-coiling Neogloboquadrina atlantica, which is found almost $50 \mathrm{~m}$ below the magnetostratigraphically defined boundary. However, its stratigraphic distribution in high-latitude areas is only poorly known. Other useful datum planes come from calcareous nannofossils and palynomorphs.

The stratigraphic record of Site 644 is correlated with Sites 642 and 643 . The biostratigraphic and magnetostratigraphic correlations between the three sites are aided by the tephra stratigraphy.

\section{NATURE AND COMPOSITION OF THE VORING MARGINAL HIGH}

\section{Sedimentary Seismic Stratigraphy}

Several regional reflectors correspond to sediment horizons in the section that overlie the prominent seismic marker EE defining the marginal high (Caston, 1976; Hinz et al., 1984; Mutter, 1984). Seismically, the post-lower Eocene sequence is composed of an upper, highly stratified section and a lower, less-distinct section, separated by a well-defined seismic marker (Fig. 7, Chapter 1). Using ties to DSDP Leg 38 drill sites, most investigators have interpreted this main intrasedimentary reflector at the Vøring Plateau as representing the decrease in global sea level at mid-Oligocene times. On the other hand, Skogseid (1983) and Skogseid and Eldholm (unpublished) have continued the Cenozoic seismic stratigraphy established on the Norwegian continental shelf (Bøen et al., 1984) onto the outer Vøring Plateau. Although the correlation across the Vøring Plateau Escarpment is not without ambiguities in the Paleogene, this procedure indicates that the intrasedimentary marker at the marginal high corresponds to reflector $\mathrm{A}$ dated as base, or lowermost, Miocene.

Through drilling results we have dated three reflectors that correspond to regional reflectors. These reflectors had been recognized earlier on the adjacent continental shelf by drilling and in seismic data. These are the base Pliocene $(\mathrm{O})$, base Miocene (A), and mid-Oligocene ( $\left.\mathrm{A}^{\prime}\right)$ reflectors. Moreover, our data appear to confirm the inferences by Skogseid (1983), which tie the outer margin reflectors to those of the basin and also demonstrate the need for some reevaluation of the seismic stratigraphy. It is possible that the duration of the hiatus near the base of the Miocene at Sites 642 (Figs. 5 and 7) and 643 is related to the relief seen in reflector EE. If this assumption is correct, Site 642, 
which is located near the most elevated part of EE, may still have been in shallow water at the end of the Oligocene.

In general, there is an excellent correspondence between the acoustic impedance logs, calculated from physical-properties measurements, and the seismic record. Most sedimentary reflectors correlated with coring results on Leg 104 are associated with changes in the sedimentation rate or unconformities. In addition, the negative impedance contrast associated with biogenic gas accumulations at Site 644 gives rise to a seismic event.

A surprising result was that the sediment seismic velocities calculated from the drilling depths to intervals of the seismic record yielded much lower values than surface measurements (Myhre, 1984). Values in the range 1.65-1.70 km/s appear representative of the drilled sections. Consequently, the sedimentary thicknesses are somewhat smaller than earlier anticipated.

\section{The Seaward-Dipping Reflector Sequence}

During DSDP Leg 38, Sites 338 and 342 were drilled a short distance into reflector EE at the outer Vøring Plateau (Talwani, Udintsev, et al., 1976). A highly altered basalt, interpreted as a sill or dike, was encountered at Site 338 , whereas slightly altered, oxidized, fine- to medium-grained basalt representative of a thick flow or dike was drilled at Site 342 . These rocks, dated by the potassium-argon method, are 46.6 and $44.0 \mathrm{Ma}$, respectively (Kharin et al., 1976). On the other hand, the oldest sediment overlying basalt at Site 338 is of early Eocene age. Subsequently, reflector EE has been taken to represent the top of a volcanic unit laid down in the early Eocene. Site 642 shows that this prominent marker reflector originates at the transition between the base of lithologic Unit IV and the top of the upper volcanic series. At this level there is a marked change in the seismic velocity and density, giving rise to a pronounced acoustic impedance contrast. The irregular, small-scale relief in reflector $\mathrm{EE}$ is probably related to the termination of individual flow surfaces rather than to faulting. Local erosion and time differences in the deposition of the individual flows suggest that the top of the volcanic series does not necessarily represent an isochronal boundary, as has often been implied.

A major drilling achievement of Site 642 was the penetration of the entire dipping-reflector sequence. For the first time the nature and composition of a sequence of seaward dipping reflectors have been convincingly demonstrated. The reflector package consists of cyclic sequences of tholeiitic basalt flows and interbedded volcaniclastic sediments. By integrating the drilling data with the seismic record and the vertical seismic profiling (VSP) experiment, we demonstrated that the reflector sequence corresponds to the upper volcanic series described previously. Earlier interpretations either assumed that the dipping reflectors at the Vøring Plateau were of predominantly volcanic nature (Hinz and Weber, 1976; Eldholm et al., 1979; Mutter et al., 1982) or consisted primarily of sedimentary beds lying unconformably beneath a lower Eocene flow unit (Bally, 1983).

Individual flows and sediment layers are not sufficiently thick to give rise to the observed dipping horizons. It is more likely that superimposed signals from composite rock units cause this effect. The individual flow units in the upper series can be grouped into larger groups consisting of fine- or medium-grained basalts. Although these flows are chemically similar, their physical properties differ. Our calculations indicate that the transitions between these two groups often produce reflection coefficients of a magnitude sufficient to produce the reflection events in the seismic record. Although the most prominent dipping interfaces occur west of Site 642 in the dipping wedge, seismic events at this drill site have been tied directly to distinct excursions in the acoustic impedance curve associated with changes between fine- and medium-grained basalts.

\section{The Base of the Seaward-Dipping Reflector Sequence (Reflector K)}

Site 642 was placed at the innermost part of the seaward dipping reflector sequence in an attempt to reach the rocks at the base of this wedge-like formation. This base is generally believed to be defined by a reflector named " $\mathrm{K}$ " by Talwani et al. (1983) and Hinz et al. (1984). Reflector K is a continuous horizon beneath the inner part of the wedge and marks the upper part of a series of low-frequency signals at the base of the dipping beds, some of which overlap reflector K (Figs. 77 and 82, Site 642 chapter). We believe that our drilling goal was reached at Site 642 , and that the top of the low-frequency band of reflectors corresponds to the 7 -m-thick volcaniclastic bed that defines the transition between the significantly different rock complexes forming the upper and lower volcanic series (Fig. 10). This inference is confirmed by the VSP experiment.

The chemical and petrographical differences between the two volcanic series are also reflected in physical properties such as compressional velocity and density of the flows, further substantiating a major geological boundary at this level. Actually, the boundary between the two volcanic series is associated with a decrease in both seismic velocity and density. Calculations based on the average shipboard laboratory measurements for the flows on either side of the series boundary yield a reflection coefficient of about -0.30 , a value expected to produce a strong signal in the seismic record. However, additional speculation as to the nature and origin of reflector $\mathrm{K}$ requires detailed seismic modeling (synthetic seismic section and VSP analysis), based on the physical rock properties and well-logging profiles for Site 642 . It is possible that the low-frequency reflector band could be caused by a transition zone found between the volcanic series and a more seismically unstructured section below. Finally, some signals in the band of low-frequency reflectors below reflector $\mathrm{K}$ might originate from reverberations and internal multiples.

The various models proposed to account for reflector $\mathrm{K}$ were not supported by Leg 104 drilling. Hinz et al. (1984) proposed that reflector $\mathrm{K}$ represents the upper Mesozoic surface that existed prior to the commencement of seafloor spreading, but this does not fit our data. We cannot rule out their idea of continental crust or fragments beneath the lower series, but our results indicate it is more likely to be rocks similar to the continental basement. There is no evidence for a lava-dike boundary as suggested by Mutter et al. (1982), nor a transition between flows deposited during an early Eocene regional volcanic event and existing older oceanic crust (layer 2 or Icelandic-type) as suggested by Eldholm et al. (1979).

\section{Models for Emplacement of the Volcanic Series}

The most significant observation found in the lower volcanic series is its more acidic flow composition, compared with the upper series. Two magma types are found in the lower series. The upper part of the series is classified as peraluminous andesites (dacites) derived from a probable crustal melt containing metasediments of shale to graywacke composition. The lowermost flows are basaltic andesites formed by mixing of tholeiitic and sialic melts. The two depleted tholeiitic dikes in the lower series also show evidence of upper crustal contamination, a fact further substantiated by the existence of mica and quartz of continental origin in the interbedded sediments. Although the emplacement history of these rock assemblages is not entirely clear, we propose a continental rift environment. The constant negative magnetic polarity throughout the volcanic sequence and the subaerial nature of the flows might indicate a late rift stage with a short time span between the emplacement of the two volcanic series. 
The upper series is characterized as Icelandic-type basalt formed by subaerial seafloor spreading. A number of geophysical and geological indicators reveal strong affinities of these basalts with other Paleogene plateau basalts belonging to the North Atlantic, or Brito-Arctic, Volcanic Province. In particular, the similarity with the lower Eocene basalts in East-Greenland and the Faeroe Islands is striking (Upton et al., 1984; Berthelsen et al., 1984). These areas, as well as the Jan Mayen Ridge and the Faeroe-Shetland and Vøring marginal highs, were all located close to each other during the early opening of the Norwegian-Greenland Sea (Talwani and Eldholm, 1977). Thus, a regional volcanic surge in the early Eocene associated with an emerged rift axis may have contributed toward the formation of the marginal highs and the seaward-dipping reflector sequences.

An evolutionary model for the outer Vøring Plateau has to be consistent not only with the DSDP and ODP drilling results, but also conform with the large amount of geophysical data in the Norwegian Sea. The existing models for the formation of seaward-dipping reflector sequences (Roberts et al., 1979; Hinz, 1981; Mutter et al., 1982; Smythe et al., 1983; Roberts et al., 1984) all satisfy some of the data, particularly with respect to the nature of the dipping sequence. However, in terms of all drilling results and geophysical data, none of the models is entirely adequate.

A final emplacement model depends critically on the shorebased dating of the flows and interbedded sediments; hence, we presently refrain from additional speculation. However, we point out that the emplacement history in a volcanic-type passive margin suggested by Skogseid and Eldholm (unpublished) could provide a basis for this study. Their model, which brings together elements from Hinz (1981) and Mutter et al. (1982), was developed to explain conjugate dipping sequences at the Jan Mayen Ridge and the Norwegian margin, as well as to take into account early Cenozoic shifts in the location of spreading axis and fracture zones. According to Skogseid and Eldholm (unpublished), the continental crust is strongly attenuated by intrusives during the late rift stage (Fig. 11). During the same stage, acidic lavas of short flow-lengths deposited at the surface form the incipient reflector K. During the subsequent break-up of the continental crust there is an initial uplift, and the earliest oceanic crust is formed subaerially. As the basic lava has better flow properties than the late rift extrusives, it may also cover part of the attenuated continental crust. Thermal contraction and perhaps a diminishing volcanic surge causes differential subsidence, and the characteristic curvature of the dipping sequence is obtained. Eventually, the subsidence reaches depths at which normal oceanic crust is generated.

In terms of the much-debated location of the continent-ocean boundary, the present drilling results favor a position seaward of Site 642. There, as noted by Skogseid and Eldholm (unpublished), reflector K can only confidently be extended below the innermost part of the dipping wedge, restricted to a region between the Vøring Plateau Escarpment and the magnetic shoulder anomaly landward of anomaly 24B (Fig. 1). We suggest, from present results, that well-defined oceanic crust first occurs a short distance landward of anomaly 24B, that is, just seaward of Site 642 .

\section{EVOLUTION OF THE CENOZOIC DEPOSITIONAL ENVIRONMENT}

\section{Paleogeographic and Paleobathymetric History}

The Vøring Plateau has experienced important paleogeographic and paleobathymetric changes that influenced the nature of the depositional environments there through time. At present, we cannot provide quantitative reconstructions of the Vøring
Plateau paleophysiography, but the available data from Sites 642 and 643 offer some constraints as to:

1. The early/middle Eocene depositional environments of the volcanic series at Site 642 , which reveals a predominantly subaerial emplacement history.

2. The subsidence of the sediment surface (as documented by the benthic foraminiferal faunas at Site 642) from shelf and upper slope to bathyal depths during Eocene to Recent times.

3. The deep-water depositional environment documented by the Paleogene sediments directly overlying the Site 643 basement rocks.

None of these data are easily reconciled with the normal thermal subsidence models for oceanic crust or continental margins, probably because of the Paleogene volcanic events. It appears that the Vøring Plateau was a peninsula or an island between the Fennoscandian and Greenland land masses in earlymiddle Eocene times, which later subsided below sea level due both to thermal cooling of the underlying crust and to tectonic events affecting this part of the Norwegian continental margin (Fig. 11).

\section{Sediment Diagenesis}

The components making up the pelagic to hemipelagic sediment layers at Site 643 have experienced heavy alteration since their primary deposition. It is obvious that dissolution has removed an important, though not quantified, portion of the calcareous microfossil assemblages, especially in the lower Miocene to Eocene sections. Calcareous material in these sediments is only occasionally preserved in thin beds. There are obvious differences in consolidation and diagenetic histories in Units III and IV at Site 643 , which suggests that a significant tectonic and/or erosional event caused a major hiatus between the units. Compressed sedimentary structures and physical properties in the lower lithologic units document an important history of consolidation and alteration caused by diagenetic processes that will have to be investigated further. Some of the sediments in Unit IV are extensively compaction-laminated and lithified, and some of the nannofossil oozes are almost completely altered by early diagenesis and recalcitization. The pore-water chemistry at both Sites 642 and 643 suggests that substantial, postburial, diagenetic changes have altered these sediments.

Comparisons between the Neogene ash layers and the volcaniclastic sequences in Unit V at Site 643 and Unit IV at Site 642 reveal that the volcanogenic components within the former unit have been particularly altered because of diagenetic processes.

Although no petroleum-related compounds were detected at Site 644 , low concentrations of hydrocarbon gases related to very early thermal, diagenetic processes were measured toward the bottom of the hole. Pyrolysis of Site 644 sediment organic matter suggests it is terrestrial in source and very immature. The interstitial-water chemistry of these Vøring Basin sediments is typical for a hemipelagic environment with high sedimentation rates and abundance of organic carbon.

\section{Paleogene Paleoclimatology and Paleoceanography}

Evidence used to describe Paleogene paleoclimate and paleoceanography comes entirely from Sites 642 and 643 . The sedimentary records of both sites supplement each other because part of the lower Miocene and Oligocene deposits lacking at Site 642 due to existence of a large hiatus, are found at Site 643.

Evidence for Paleogene paleoclimate and paleoceanography at Site 642 is based almost entirely on palynomorphs, and only occasionally is supported by the other planktonic and benthic microfossil groups. The location of the Paleogene volcanic source 
Schematic only

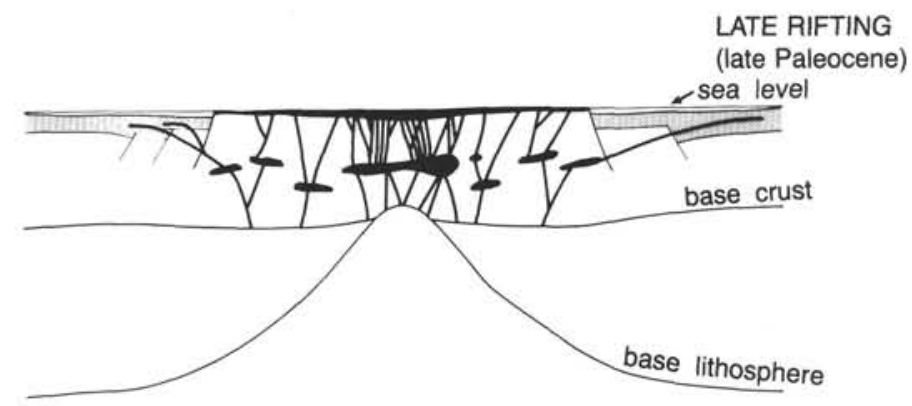

W

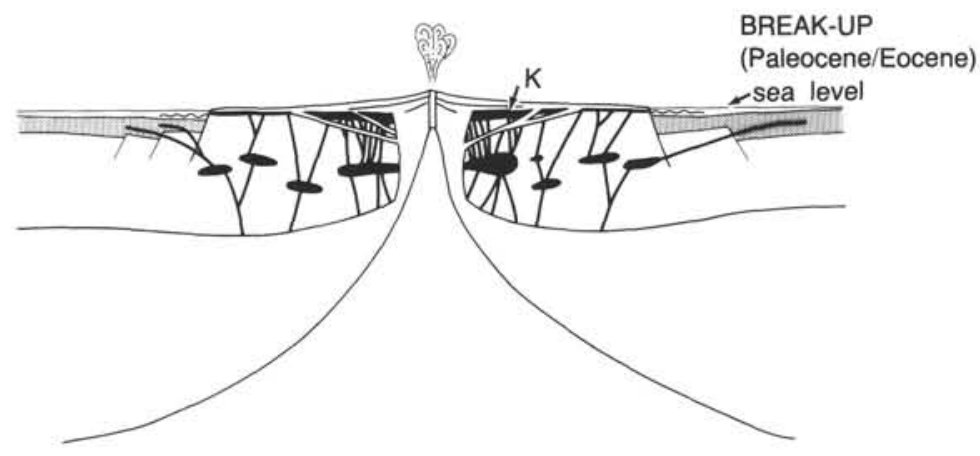

Cretaceous sediment

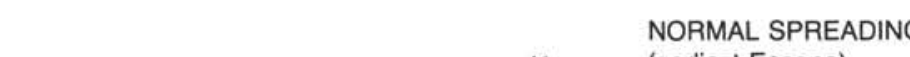

(earliest Eocene)

EE sea level
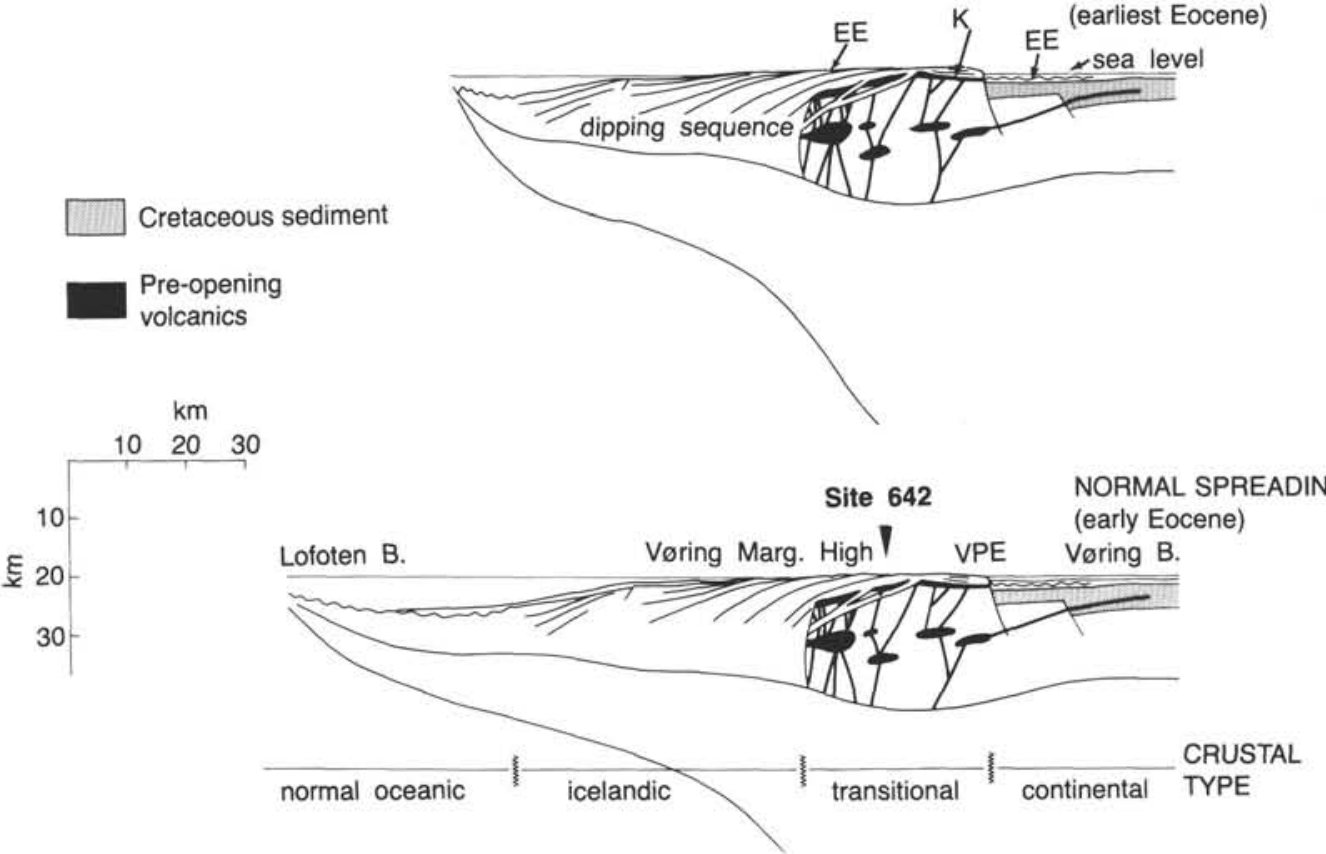

Figure 11. Schematic model for the formation of a volcanic marginal high at the Vøring Plateau (Skogseid and Eldholm, unpublished).

region is unknown; however, independent evidence from petrologic and micropaleontologic data documents that the interbedded sediments in the volcanic series represent an alternating sequence of terrestrial and subaqueous (at least partly marine) depositional environments close to the former shoreline. It is difficult to interpret these first depositional environments in terms of paleoclimate and paleoceanography. Various fauna and floral ratios within the pelagic microfossil groups, and between marine microfossils and terrestrial pollen and spores, have been used to separate neritic, estuarine-intertidal, lacustrine, and subaerial terrestrial depositional environments. In some of the intervals investigated these facies might follow each other in a systematic fashion, documenting a transgressive-regressive sequence of events.

Neritic-fluviodeltaic depositional environments are documented for the late early Eocene, although a decrease of the arboreal pollen might indicate more arid conditions. During periods in the middle Eocene the seafloor emerged and alternating neritic 
marine, fluviodeltaic, and terrestrial palynomorph assemblages appeared. A decrease of the dinocyst assemblages and absence of subtropical conifers in the upper Eocene sediments may reflect the influence of a cooling event (Norris, 1982). In general, it appears that the Paleogene volcaniclastic beds at Site 642 were deposited in a terrestrial or relatively shallow (neritic) marine environment that underwent minor changes in relative sea level. Similar paleoenvironmental reconstructions have been obtained for the Eocene volcanic sediments at DSDP Site 338 (Manum, 1976), DSDP sites on the Rockall Plateau (Costa and Downie, 1979; Brown and Downie, 1984), and at Kap Dalton (Soper et al., 1976).

Site 643 is located in considerably deeper water than Site 642. Foraminiferal data of the Site 643 Paleogene sediments suggest that these depth differences already existed during Eocene time. The arenaceous benthic foraminiferal assemblage from the Eocene section indicates a deep-water environment, possibly with terrigenous sediment transport downslope and basinal infilling. Faunal similarities with lower to middle Eocene sections from the North Atlantic and Northern Europe suggest water exchange with the regions south of the Norwegian Sea took place at this time. The absence of calcareous fossils in the lower Eocene sediments and their presence in narrow zones higher in the Eocene section indicate intervals with reduced carbonate dissolution and lowered $\mathrm{CCD}$, possibly combined with reduced terrigenous input into the bottom environment.

Restricted living conditions for planktonic organisms are indicated by the small-diversity, Eocene planktonic foraminiferal faunas, which consist of small specimens. The environmental cause for this is not clearly understood at present. Siliceous microfossils are absent in the Eocene sediments. Their absence is more likely a result of diagenetic dissolution than of nonproductive surface waters. Biosiliceous deposits from the upper Eocene have been described at adjacent DSDP Leg 38 drill sites. Palynomorph data bear evidence of a climatic cooling through the Eocene, recorded by the replacement of thermophilic floras by indicators of boreal forests.

A marked change in benthic foraminiferal faunas occurred between the Eocene and the Oligocene, indicating more restricted Oligocene environments. Because of poor time control of the Oligocene sediments it is not yet possible to address whether this change is related to regional tectonic events or global climatic and oceanographic events. The presence of carbonate-rich, fossil-bearing sediments in the Oligocene section is evidence of productive surface waters during that time, while the low diversity of the assemblages indicates distinctive environmental gradients between the Norwegian Sea and the North Atlantic.

\section{Neogene and Quaternary Paleoclimatology and Paleoceanography}

After the preliminary, but relatively precise, temporal paleobathymetric and paleogeographic framework was established from Leg 104 data, we used the various data on composition and bulk sediment properties to develop a scenario for the paleoclimate and the paleoceanography that controlled the depositional environment in the eastern Norwegian Sea during the past 24 m.y.

\section{Bottom-Water Paleoceanography}

It is difficult to describe the temporal variations in the properties of bottom waters at Site 642 because the seafloor there has subsided from, or near, sea level to about $1300 \mathrm{~m}$; however, the vertical motion has not yet been quantified properly. Furthermore, only two groups of benthic microfossils, foraminifers and sponges, are abundant throughout the Miocene to Quaternary sequence. Indications of current-induced reworking, dis- placement of sediment particles along the seafloor, and dissolution patterns of calcareous sediment particles can be used to make inferences about certain properties of the bottom waters.

The lower, and lower-middle, Miocene fossil assemblages at Site 642 are represented by a small-diversity, sparse arenaceous fauna, which might indicate severe carbonate dissolution or a relatively shallow water environment. Some of the species in this interval are known to tolerate reduced salinities. A major change in the bottom waters occurred in the middle Miocene, approximately $13.5 \mathrm{Ma}$, when a rich, calcareous benthic foraminiferal fauna appeared. This shift coincided with the establishment of the modern global deep-water circulation and a deepening of the CCD. Such a coincidence is exceptional because many scientists believe that the Greenland-Scotland Ridge functioned as a relatively effective sill between the Norwegian-Greenland Sea and the main North Atlantic Ocean during this time.

The Pliocene benthic foraminiferal assemblages at this site are similar to present assemblages, but may indicate slightly higher bottom-water temperatures. Numerous barren intervals in the Pliocene sediments suggest periods of intensive carbonate dissolution. Ice-rafted debris in the upper Pliocene sediments implies the presence of sea ice at that time. The Quaternary assemblages contain roughly the same species as the modern ones, and a number of samples yield reworked shelf foraminifers.

Bioturbation effects throughout the Neogene and Quaternary sediments are mild to intense, suggesting that the bottom waters at the site were almost always sufficiently oxygenated to support benthic organisms whose presence is documented by trace fossils. Bottom-water erosion is particularly evident in the upper Miocene part of the section, where biostratigraphic data suggest a long hiatus or a zone of drastically diminished sedimentation rates.

The lower and middle Miocene at Site 643 is characterized by carbonate-barren sediments and arenaceous benthic foraminiferal assemblages, indicative of significant carbonate dissolution. The same type of calcareous benthic fauna as at Site 642 accompanied the onset of carbonate deposition in the middle Miocene, implying a relatively unstratified deep-water body. A plausible cause for this homogenization is rapid, local, deep-water formation in the Norwegian-Greenland Sea. The same kind of benthic foraminiferal fauna is present throughout the upper Neogene, indicating unchanged deep-water circulation. A turnover in the middle Miocene benthic assemblages followed the midMiocene global turnover in benthic foraminiferal faunas. The glacial interval in the late Pliocene-Pleistocene was accompanied by rapid fluctuations in bottom-water characteristics, as evidenced by marked changes in benthic assemblages.

The deposits drilled at Site 644 document only the youngest geologic past. The benthic foraminifers there indicate slightly warmer bottom waters during deposition of the Pliocene sediments. Evidence for glaciations is found in the form of icerafted detritus (Fig. 12) and in reworked, transported shelf species, which are found abundantly in the Quaternary sequence.

\section{Surface-Water Paleoceanography}

Indications of changes in the surface-water paleoceanography are based on pelagic calcareous, siliceous, and organic-walled microfossil assemblages as well as the temporal variability in occurrences of ice-rafted, coarse, terrigenous debris in the upper Neogene and Quaternary part of the drilled sites.

The oldest Neogene time intervals, which are documented by Site 642 sediments, are difficult to interpret. During that time, the Norwegian-Greenland Sea probably was relatively isolated from the main North Atlantic basins and the Arctic Ocean. Lower Miocene, thick-walled radiolarians and dinocysts reflect temperate to cool-cold water conditions with an increasing water exchange to the North Atlantic. A major environmental 
$\mathrm{cm}$

80

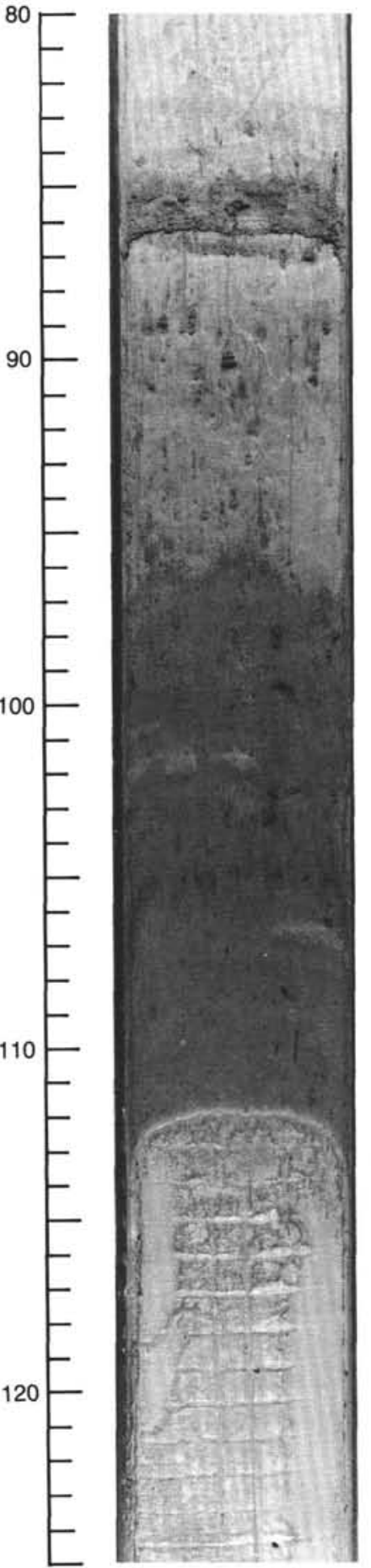

cm

10

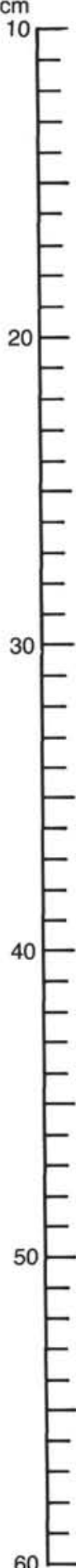

B

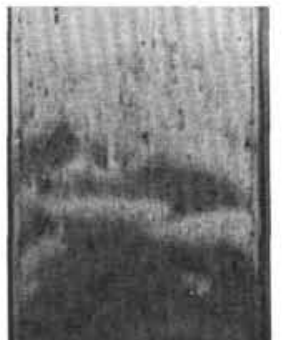

return to more thick-walled, cool-cold adapted assemblages is observed in the time span from 13.5 to $12.3 \mathrm{Ma}$. This change may reflect cooling or increased isolation of the Norwegian Sea, although the presence of the cosmopolitan planktonic foraminifer (small diversity) and calcareous nannofossil assemblages suggests cooling rather than isolation. Diatoms found in this age interval are abundant and reflect upwelling and cold surfacewater conditions.

Calcareous, as well as siliceous, plankton indicate that relatively warm surface waters existed during the late Miocene, were warmest during 7.4-5.2 Ma, and possibly continued into the early Pliocene. However, the lack of temperate calcareous zonal markers implies that an important temperature gradient existed between the main North Atlantic Ocean and the Norwegian Sea, even during this relatively warm interval.

From the early Pliocene onward the onset of increasingly cooler surface water is suggested by the planktonic microfossil assemblages at Site 642. Important quantities of coarse, terrigenous ice-rafted detritus appear close to the Matuyama/Gauss boundary, and a sudden increase in the magnetic intensity around 4.3 Ma corresponds to a change from predominantly biogenic to terrigenous sediments. Both of these records probably mark the onset of glacial-type depositional environments. The onset of ice-rafting of coarse terrigenous components (Fig. 12) had a great impact on all pelagic microfossil groups. As the Norwegian-Greenland Sea ice-cover developed over extended periods, diatoms and silicoflagellates seem to have disappeared, nannofossils, dinocysts, and planktonic foraminifers show marked decreases in their diversity, and polar faunas and floras were established. The relatively warm North Atlantic Current was deflected farther to the south during this time. This transition to a true polar depositional environment appears to have occurred somewhat earlier in the Norwegian-Greenland Sea than in the adjacent North Atlantic south of the Greenland-Scotland Ridge (Shackleton, Backman, et al., 1984).

The Site 642 Quaternary sediments are characterized by the relatively regular cyclic change between polar (glacial) and subpolar-temperate (interglacial) depositional environments, with somewhat different characteristics of the cycles during the early part of the Quaternary.

High abundances and high diversity characterize the siliceous microfossil assemblages of the lower Miocene at both Sites 643 and 642 . Thus, the onset of $\mathrm{SiO}_{2}$ preservation was not related to water depth. The lower Miocene section is expanded at Site 643 compared with Site 642 and is also more biogenic, indicating highly productive upwelling zones were once located west of Site 642. Diatom assemblages indicate that the warmest Neogene period was in the early Miocene, and warm water assemblages persist from that point to the possible middle Miocene unconformity.

Since major parts of the Pliocene sediments are absent at Site 643 , it is difficult to interpret the oceanographic conditions leading up to the onset of glacial deposition in the late Pliocene, but the corresponding oceanographic changes are thoroughly marked by all microfossil groups. Absence of siliceous microfossils indicates reduced productivity, whereas changes of lowdiversity planktonic foraminiferal and calcareous nannofossil assemblages demonstrate large scale fluctuations in the oceanic regime throughout the last $2.5 \mathrm{Ma}$.

A number of important observations related to the glacial history of the Norwegian Sea are inferred from the sediments recovered at Site 644 . The lowermost $25 \mathrm{~m}$ of Hole $644 \mathrm{~A}$ stands out as a separate lithological unit consisting of interbedded siliceous oozes and mixed siliceous nannofossil oozes. The lower sedimentary unit represents temperate interglacial or preglacial conditions, as shown by the silicoflagellate and diatom floras and the planktonic foraminiferal faunas. Because drilling termi- change affected the pelagic microfossil assemblages at about 13.5 Ma, probably correlative with the global ${ }^{18} \mathrm{O}$-enrichment and Antarctic ice-volume expansion. This interval coincides with the appearance of abundant calcareous plankton (foraminifers and nannofossils), and with important zone boundaries in the siliceous planktons. In the radiolarian assemblages, however, a 
nated at 252 mbsf, we do not know whether the sedimentary sequence older than $2.9 \mathrm{Ma}$ also contains evidence for cold climates at this location.

The most conspicuous lithostratigraphic elements of the upper lithological unit are layers of dark, carbonate-poor glacial muds. These layers typically contain coarse, terrigenous, icerafted grains up to several centimeters in diameter and occur interbedded with light interglacial sediments (Fig. 12). The transition from the preglacial to fully glacial depositional environments was gradual and occurred in three major steps, each documented by separate lithologies.

At about $2.5 \mathrm{Ma}$, fossil evidence for continuous ice-free conditions disappears, and is replaced by cold-water faunas and floras that represent surface-water masses with large and rapid intermittent changes in productivity. In the mid-Quaternary, approximately $0.73 \mathrm{Ma}$, the important but intermittently occurring portion of biogenic opal disappeared from the sediments, which suggests a drastic drop in surface-water productivity. All samples above 85.7 mbsf at Site 644 appear barren of diatoms. However, calcareous nannofossils and planktonic foraminifers continued to produce enough sediment particles during these episodes to form the calcareous muds and marly foraminifernannofossil oozes that occur as high in the stratigraphic column as Subunit IIB, approximately $0.4-0.5 \mathrm{Ma}$. Above this interval the fluctuations between glacial and interglacial depositional environments are dominated by the glacial mode. The calcareous components contribute only modestly to the upper Quaternary sediments.

The glacial depositional environments documented at Site 644 were interrupted several times by periods of temperate-towarm waters. A particular case of such an event is found between 180 and 200 mbsf at Site 644, as indicated by the silicoflagellate Dictyocha, the last abundant occurrence of diatoms (approximately $2.2 \mathrm{Ma}$ ), and by warm-temperate radiolarians, planktonic foraminifers, and palynomorphs. A similar interval is observed at $110 \mathrm{mbsf}$, at about $0.98 \mathrm{Ma}$ (close to the magnetic Jaramillo event).

Evidence for extensive glaciations at Site 644 is found in samples between 25 and 83 mbsf (approximately 0.1-0.7 Ma). These samples contain large amounts of ice-rafted materials, and shallow-water benthic foraminifers dominate the foraminiferal assemblages. The transport of this shelf material is restricted to the glacial maxima, when ice probably covered the shelf region.

The glacial sediments at Site 644 are easily correlated with the corresponding stratigraphic intervals at Sites 642 and 643. Although the latter sites do not reveal the same detail as Site 644 because of reduced sedimentation rates, they clearly show the same type of stratigraphies and similar variability in sediment composition. Some important differences, however, are evident among the three sites. An example of these differences is found in the dark glacial layers at Site 644. Here, we found frequent chalk fragments that obviously were part of the ice-rafted assemblages; however, these chalks do not occur at Sites 642 and 643 , which suggests that icebergs from a different source region delivered this material.

\section{Paleoclimatology of Adjacent Land Areas}

The Site 642 Neogene and Quaternary palynomorph assemblages contained abundant portions of isochronous pollen and spores, as well as reworked material from older formations. The latter assemblages will not be dealt with because they may have been eroded from outcrops at the nearby shelf, transported by ice, or transported as suspended material from distant sources. The isochronous pollen and spores, however, bear important information about paleoclimates of the adjacent land regions. The source regions of the pollen and spores cannot be determined precisely, and we note that the paleoceanographic inter- pretation of the marine pelagic microfossil data and the paleoclimates suggested by the pollen and spores do not correspond completely in our preliminary analyses.

The Oligocene-early Miocene paleoclimate appears to have been a cool stage, as evidence of subtropical conifers is not found in the palynomorph assemblages. During the late early Miocene, boreal warm-temperate forests grew on the adjacent continent. The early middle Miocene floras are characterized by boreal and thermophilic forests onshore. Boreal to warm temperate-subtropical forests covered the late middle Miocene land surfaces. The increase of thermophilic hardwood species and a reduction in ferns in the late middle Miocene suggest that this period was drier than times both before and after. Boreal-temperate floras, alternating with boreal and relatively warm and moist intervals, prevailed in the late Miocene and the main part of the Pliocene, slowly retreating toward boreal forests and a forest-tundra vegetation in the Quaternary.

Except for lower pollen and spore abundances, which simply reflect the longer distance from the coastline at Site 643, the palynomorph assemblages are similar to those at Site 642 .

\section{Neogene and Quaternary Northern Hemisphere Paleoclimate}

ODP Leg 104 recovered sediments of great significance for understanding the evolution and variability of the Northern Hemisphere paleoclimate during the past 10-30 m.y. Prior to this cruise, no long and detailed pelagic sedimentary record was available from the sub-Arctic. Available Arctic Ocean sediment cores are, in general, too short or have questionable stratigraphic properties (Clark et al., 1980) for extensive paleoclimate analyses, and those from the Norwegian-Greenland Sea are either stratigraphically short (Thiede et al., 1986) or do not provide the necessary stratigraphic detail (Talwani, Udintsev, et al., 1976). Sites 642 and 644 are the first piston-cored deep-sea drill sites in a truly northern polar deep-sea basin.

Our preliminary results provide indications for the initiation of glacial-type erosional regimes on land near the Vøring Plateau as early as $4.3 \mathrm{Ma}$. This date is almost $2 \mathrm{Ma}$ earlier than the 2.3-2.4-Ma date derived from drill sites south of the Greenland-Scotland Ridge (Shackleton, Backman, et al., 1984). The age for the initiation of northern glacial-type depositional environments at the Vøring Plateau is, however, preceded by the 5- to 6-Ma ice-rafted Arctic Ocean sediments (Clark et al., 1980). In addition to information about the onset of Arctic glaciation, Leg 104 cores provide the material needed to describe the paleoceanographic and paleoclimatic variations leading to the glacial scenario. Furthermore, using these cores we can identify a period of late Cenozoic glacial-interglacial cycles, documented by more than 20 horizons with coarse, ice-rafted, terrigenous debris and interlayered sediment.

It is particularly interesting to note that the Northern Hemisphere paleoclimatic evolution in the late Cenozoic closely corresponds to a set of similar events in the Southern Hemisphere. The cessation of preglacial conditions at Site 644 occurred almost simultaneously with a major northward expansion of Antarctic polar waters beginning about $2.8 \mathrm{Ma}$. Our results show that numerous climatic fluctuations have occurred since that time, leading to an increasingly more glacial oceanic depositional environment in both the Northern and Southern Hemispheres.

\section{REFERENCES}

Bally, A. W. (Ed.), 1983. Seismic expression of structural styles: AAPG, Studies in Geology, 15:2 vols.

Berthelsen, O., Noe-Nygaard, A., and Rasmussen, J. (Eds.), 1984. The deep drilling project 1980-1981 in the Faeroe Islands. Ann. Soc. Sci. Faroensis, Suppl. IX. 
Bøen, F., Eggen, S., and Vollset, J., 1984. Structures and basins of the margin from $62-69^{\circ} \mathrm{N}$ and their development. In Spencer, A. M. (Ed.), Petroleum Geology of the North European Margin: London (Graham and Trotman), 253-270.

Brown, S., and Downie, C., 1984. Dinoflagellate cyst biostratigraphy of late Paleocene and early Eocene sediments from Holes 552, 553A, and 555, Leg 81, Deep Sea Drilling Project (Rockall Plateau). In Roberts, D. G., Schnitker, D., et al., Init. Repts. DSDP, 81: Washington (U.S. Govt. Printing Office), 565-579.

Caston, V. N. D., 1976. Tertiary sediments of the Vøring Plateau, Norwegian Sea, recovered by Leg 38 of the Deep Sea Drilling Project. In Talwani, M., Udintsev, G., et al., Init. Repts. DSDP, 38: Washington (U.S. Govt. Printing Office), 761-782.

Clark, D. L., Whitman, R. R., Morgan, K. A., and Mackey, S. D., 1980. Stratigraphy and glacial marine sediments of the Amerasian Basin, central Arctic Ocean. Geol. Soc. Am. Spec. Pap., 181.

Costa, L. I., and Downie, C., 1979. Cenozoic dinocyst stratigraphy of Sites 403 to 406 (Rockall Plateau), IPOD, Leg 48. In Montadert, L., Roberts, D. G., et al., Init. Repts. DSDP, 48: Washington (U.S. Govt. Printing Office), 513-529.

Donn, W. L., and Ninkovich, D., 1980. Rate of Cenozoic explosive volcanism in the North Atlantic Ocean inferred from deep sea cores. $J$. Geophys. Res., 85:5455-5460.

Eldholm, O., Sundvor, E., and Myhre, A., 1979. Continental margin off Lofoten-Vesteralen, northern Norway. Mar. Geophys. Res., 4: 3-35.

Eldholm, O., Sundvor, E., Myhre, A. M., and Faleide, J. I., 1984. Cenozoic evolution of the continental margin off Norway and western Svalbard. North European Margin Symp. Proc. Norw. Pet. Soc.: London (Graham and Trotman), 3-18.

Hinz, K., 1981. A hypothesis on terrestrial catastrophes. Wedges of very thick ocean and dipping layers beneath passive continental marginstheir origin and paleoenvironment significance. Geol. Jb., E22:3-28.

Hinz, K., Dostman, H. J., and Hanisch, J., 1984. Structural elements of the Norwegian continental margin. Geol. Jb., A75:193-221.

Hinz, K., and Weber, J., 1976. Zum geologischen Aufbau des Norwegischen Kontinentalrandes und der Barents-See nach reflexionsseismischen Messungen. Erdöl, Kohle, Erdgas, Petrochemie, Compendium 1975/76, 3-29.

Kharin, G. N., Udintsev, G. B., Bogafikov, O. A., Dmitriev, J. I., Raschka, H., Kreuzer, H., Mohr, M., Hane, W., and Eckhardt, F. J., 1976. K/Ar ages of the basalts of the Norwegian-Greenland Sea, DSDP Leg 38. In Talwani, M., Udintsev, G., et al., Init. Repts. DSDP, 38: Washington (U.S. Govt. Printing Office), 755-760.

Manum, S. B., 1976. Dinocysts in Tertiary Norwegian-Greenland Sea sediments (Deep Sea Drilling Project Leg 38), with observations on palynomorphs and palynodebris in relation to environment. In Talwani, M., Udintsev, G., et al., Init. Repts. DSDP, 38: Washington (U.S. Govt. Printing Office), 897-919.
Mutter, J. C., 1984. Cenozoic and late Mesozoic stratigraphy and subsidence history of the Norwegian margin. Bull. Geol. Soc. Am., 95: 1135-1149.

Mutter, J. C., Talwani, M., and Stoffa, P. L., 1982. Origin of seawarddipping reflectors in oceanic crust of the Norwegian margin by "subaerial sea-floor spreading." Geology, 10:353-357.

Myhre, A. M., 1984. Compilation of seismic velocity measurements along the margins of the Norwegian-Greenland Sea. Norsk Polarinst. Skr., 180:41-61.

Norris, G., 1982. Spore-pollen evidence for early Oligocene high-latitude cool climatic episode in northern Canada. Nature, 297:387-389.

Roberts, D. G., Backman, J., Morton, A. C., Murray, J. W., and Keene, J. B., 1984. Evolution of volcanic rifted margins: Synthesis of leg 81 results on the west margin of Rockall Plateau. In Roberts, D. G., Schnitker, D., et al., Init. Repts. DSDP, 81: Washington (U.S. Govt. Printing Office), 883-911.

Roberts, D. G., Montadert, L., and Searle, R. C., 1979. The western Rockall Plateau stratigraphy and structural evolution. In Montadert, L., Roberts, D. G., et al., Init. Repts. DSDP, 48: Washington (U.S. Govt. Printing Office), 1061-1088.

Shackleton, N. J., Backman, J., et al., 1984. Oxygen isotopic calibration of the onset of ice-rafting and the history of glaciation in the North Atlantic region. Nature, 307:620-623.

Skogseid, J., 1983. A marine geophysical study of profiles between the Vøring Plateau margin and the Jan Mayen Ridge. [Cand. Sci. thesis]. University of Oslo, Oslo.

Smythe, D. K., Chalmers, J. A., Skuce, A. G., Dobinson, A., and Mould, A. S., 1983. Early opening history of the North Atlantic-I. Structure and origin of the Faeroe-Shetland Escarpment. Geophys. J. Roy. Astr. Soc., 72:373-398.

Soper, N. J., Downie, C., Higgins, A. C., and Costa, L. I., 1976. Biostratigraphic ages of Tertiary basalts on the East Greenland continental margin and their relationship to plate separation in the northeast Atlantic. Earth Planet. Sci. Lett., 32:149-157.

Talwani, M., and Eldholm, O., 1977. Evolution of the Norwegian-Greenland Sea. Bull. Geol. Soc. Am., 83:3575-3608.

Talwani, M., Mutter, J., and Hinz, K., 1983. Ocean continent boundary under the Norwegian continental margin. In Bott, M. H. P., Saxov, S., Talwani, M., and Thiede, J. (Eds.), Structure and Development of the Greenland-Scotland Ridge-New Methods and Concepts: New York (Plenum Press), 121-131.

Talwani, M., and Udintsev, G., et al., 1976. Init. Repts. DSDP, 38: Washington (U.S. Govt. Printing Office).

Thiede, J., Diesen, G. W., Knudsen, B. E., and Snaare, T. W., 1986. Patterns of Cenozoic sedimentation in the Norwegian-Greenland Sea. Mar. Geol., 69:323-352.

Upton, B.G.J., Emeleus, C. H., and Beckinsale, R. D., 1984. Petrology of the northern East Greenland Tertiary flood basalts: evidence from Hold with Hope and Wollaston Foreland. J. Petrol., 25:151-184. 